\title{
SCWR Once-Through Calculations for Transmutation and Cross Sections
}

\author{
Francesco Ganda
}

July 2012

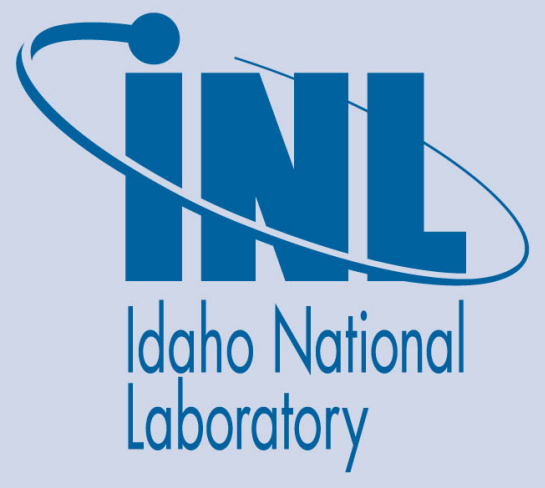

The INL is a U.S. Department of Energy National Laboratory operated by Battelle Energy Alliance 
INL/EXT-12-26622

FCRD-FCO-2012-000184

\title{
SCWR Once-Through Calculations for Transmutation and Cross Sections
}

\author{
Francesco Ganda
}

July 2012

\section{Idaho National Laboratory \\ Fuel Cycle Research \& Development \\ Idaho Falls, Idaho 83415}

http://www.inl.gov

Prepared for the

U.S. Department of Energy

Assistant Secretary for Fossil Energy

Under DOE Idaho Operations Office

Contract DE-AC07-05ID14517 


\section{DISCLAIMER}

This information was prepared as an account of work sponsored by an agency of the U.S. Government. Neither the U.S. Government nor any agency thereof, nor any of their employees, makes any warranty, expressed or implied, or assumes any legal liability or responsibility for the accuracy, completeness, or usefulness, of any information, apparatus, product, or process disclosed, or represents that its use would not infringe privately owned rights. References herein to any specific commercial product, process, or service by trade name, trade mark, manufacturer, or otherwise, does not necessarily constitute or imply its endorsement, recommendation, or favoring by the U.S. Government or any agency thereof. The views and opinions of authors expressed herein do not necessarily state or reflect those of the U.S. Government or any agency thereof. 


\section{SUMMARY}

It is the purpose of this report to document the calculation of (1) the isotopic evolution and of (2) the 1group cross sections as a function of burnup of the reference Super Critical Water Reactor (SCWR), in a format suitable for the Fuel Cycle Option Campaign Transmutation Data Library. The reference SCWR design was chosen to be that described in [McDonald, 2005].

Super Critical Water Reactors (SCWR) are intended to operate with super-critical water (i.e. $\mathrm{H}_{2} \mathrm{O}$ at a pressure above $22 \mathrm{MPa}$ and a temperature above $373^{\circ} \mathrm{C}$ ) as a cooling - and possibly also moderating fluid. The main mission of the SCWR is to generate lower cost electricity, as compared to current standard Light Water Reactors (LWR). Because of the high operating pressure and temperature, SCWR feature a substantially higher thermal conversion efficiency than standard LWR - i.e. about $45 \%$ versus $33 \%$, mostly due to an increase in the exit water temperature from $\sim 300^{\circ} \mathrm{C}$ to $\sim 500^{\circ} \mathrm{C}$ - potentially resulting in a lower cost of generated electricity. The coolant remains single phase throughout the reactor and the energy conversion system, thus eliminating the need for pressurizers, steam generators, steam separators and dryers, further potentially reducing the reactor construction capital cost. The SCWR concept presented here is based on existing LWR technology and on a large number of existing fossilfired supercritical boilers.

However, it was concluded in [McDonald, 2005], that: "Based on the results of this study, it appears that the reference SCWR design is not feasible." This conclusion appears based on the strong sensitivity of the design to small deviations in nominal conditions leading to small effects having a potentially large impact on the peak cladding temperature of some fuel rods. "This was considered a major feasibility issue for the $S C W R$ " [McDonald, 2005]. However, it was beyond the scope of this report to further investigate this issue and to confirm or rebut these findings, since they appear to be mostly based on thermal-hydraulic considerations, while this report is focused on the reactor physics aspects of the design.

After a description of the reference SCWR design, the Keno V 3-D single assembly model used for this analysis, as well as the calculated results, are presented.

Additionally, the following information, presented in the appendixes, is intended to provide enough guidance that a researcher repeating the same task in the future should be able to obtain a vector of nuclei and cross sections ready for insertion into the transmutation library without any need for further instructions:

(1) Complete TRITON/KENO-V input used for the analysis;

(2) Inputs and detailed description of the usage of the OPUS utility, used to postprocess and to extract the nuclei concentrations for the transmutation library;

(3) Inputs and detailed description of the usage of the XSECLIST utility, used to postprocess and to extract the 1-group cross sections for the transmutation library;

(4) Details of an ad-hoc utility program developed to sort the nuclei and cross sections for the transmutation library. 


\section{CONTENTS}

SUMMARY

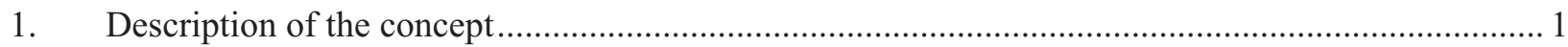

1.1 Neutronic computational model used in [McDonald, 2005] ................................................ 4

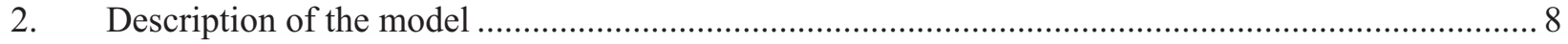

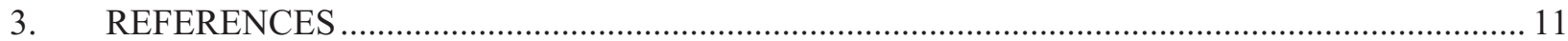

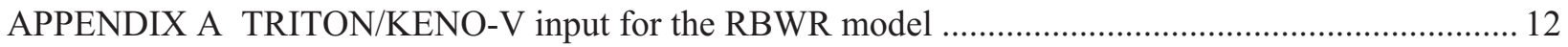

APPENDIX B OPUS input and nuclide concentrations post-processing ............................................ 21

APPENDIX C XSECLIST input and cross sections post-processing .................................................. 22

APPENDIX D SCALE_XSLIST_READER for the conversion of OPUS and XSECLIST outputs to the standard format of the transmutation library

\section{FIGURES}

Figure 1-1. Conceptual design of the reference SCWR pressure vessel and internals, from [McDonald, 2005]. 2

Figure 1-2. The SCWR fuel assembly with metal water rod boxes, from [McDonald, 2005].................. 4

Figure 2-2. SCWR spectra at BOL in the fuel at the bottom, center and top of the core.......................... 9

Figure 2-3. Evolution with burnup of the radially-reflected burnup...................................................... 10

\section{TABLES}

Table 1-1. Conceptual reference SCWR reference design power and coolant conditions. From [McDonald, 2005]. 3

Table 1-2. Reference reactor core design for the reference SCWR. From [McDonald, 2005].................... 3

Table 1-3. Reference fuel assembly design for the reference SCWR. From [McDonald, 2005].................. 3

Table 1-4. Reference fuel pin design for the reference SCWR. From [McDonald, 2005] ......................... 4

Table 1-5. Major elemental constituents for MA956, Alloy 718, Zircaloy-4, and SiC. From

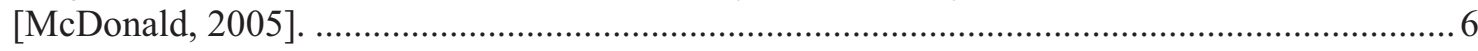

Table 1-6. Assembly lattice k-infinity for four different clad materials. From [McDonald, 2005]............ 6

Table 1-7. Converged beginning-of-life SCWR water densities for the coolant. From [McDonald, 2005]. 


\section{ACRONYMS}

\begin{tabular}{|l|l|}
\hline BU & Burnup (in GWD/MTiHM) \\
\hline EFPD & Evaluated Full Power Days \\
\hline EFPY & Evaluated Full Power Years \\
\hline GWD/MTiHM & GigawatDays per Metric Ton of Initial Heavy Metal \\
\hline HM & Heavy Metal \\
\hline LWR & Light Water Reactor \\
\hline MT & Metric Ton \\
\hline PWR & Pressurized Water Reactor \\
\hline SCWR & Super Critical Water Reactor \\
\hline XS & Cross Sections \\
\hline
\end{tabular}





\section{SCWR ONCE-THROUGH CALCULATIONS FOR TRANSMUTATION AND CROSS SECTIONS}

It is the purpose of this report to document the calculation of (1) the isotopic evolution and of (2) the 1group cross sections as a function of burnup of the reference Super Critical Water Reactor (SCWR). The reference SCWR design was chosen to be that described in [McDonald, 2005].

Section 1 provides a description of the reference SCWR design, its main features and the neutronic computational model used in [McDonald, 2005].

Section 2 describes the Keno V 3-D single assembly model used for the results produced for this work. Appendix A provides the complete TRITON/KENO-V input used for the analysis. Appendix B and C provide a detailed description and the inputs of, respectively, the OPUS and XSECLIST post processing used to extract the transmutation library data. Appendix D describes in detail the procedure for using a utility program developed to sort the nuclei and cross sections for the transmutation library.

The description in the appendixes is intended to provide enough guidance that a researcher repeating the same task in the future should be able to obtain a vector of nuclei and cross sections ready for insertion into the transmutation library without any need for further instructions.

\section{Description of the concept}

Super Critical Water Reactors (SCWR) are intended to operate with super-critical water (i.e. $\mathrm{H}_{2} \mathrm{O}$ at a pressure above $22 \mathrm{MPa}$ and a temperature above $373^{\circ} \mathrm{C}$ ) as a cooling - and possibly also moderating fluid. The main mission of the SCWR is to generate lower cost electricity, as compared to current standard Light Water Reactors (LWR). Because of the high operating pressure and temperature, SCWR feature a substantially higher thermal conversion efficiency than standard LWR - i.e. about $45 \%$ versus $33 \%$, mostly due to an increase in the exit water temperature from $\sim 300^{\circ} \mathrm{C}$ to $\sim 500^{\circ} \mathrm{C}$ - potentially resulting in a lower cost of generated electricity. The coolant remains single phase throughout the reactor and the energy conversion system, thus eliminating the need for pressurizers, steam generators, steam separators and dryers, further potentially reducing the reactor construction capital cost. The concept is based on existing LWR technology and on a large number of existing fossil-fired supercritical boilers.

However, it was concluded in [McDonald, 2005], that: "Based on the results of this study, it appears that the reference SCWR design is not feasible." This conclusion appears based on the strong sensitivity of the design to small deviations in nominal conditions leading to small effects having a potentially large impact on the peak cladding temperature of some fuel rods. "This was considered a major feasibility issue for the SCWR" [McDonald, 2005].

The conceptual SCWR design used as reference for this work is shown in Figure 1-1, while the reference design and coolant conditions are shown in Table 1-1 (from [McDonald, 2005]). It is noted in particular the thermal efficiency level of $44.8 \%$, substantially higher than that of standard LWR.

Key characteristics of the design are:

- $25 \mathrm{MPa}$ system pressure;

- Inlet and outlet temperatures of $280^{\circ} \mathrm{C}$ and $500^{\circ} \mathrm{C}$ respectively;

- Water density changes across the core from $760 \mathrm{~kg} / \mathrm{m}^{3}$ to $90 \mathrm{~kg} / \mathrm{m}^{3}$;

- $90 \%$ of the total inlet flow goes to the top plenum, and then flows downwards in special water rods to the bottom plenum, where it mixes with the remaining $10 \%$ inlet flow before passing through the active core. This arrangement is designed to provide additional moderation in the upper part of the core. 
The vessel is similar in dimensions to that of a standard PWR, but thicker because of the higher pressure. The vessel material is envisioned to be SA-533 or SA-508, Grade3, Class 1, and cladded with stainless steel 308 (from [McDonald, 2005]).

The parameters necessary for the neutronic calculations are shown in Tables 1-2 to 1-4 (from [McDonald, 2005]), and a radial view of the reference fuel assembly is shown in Figure 1-2.

Each assembly will have 1 instrumentation tube in the center, and the control rods are inserted in the water channels. Each assembly has 36 water rods and $300 \mathrm{UO}_{2}$ active fuel pin; the average linear heat rate is $19.2 \mathrm{~kW} / \mathrm{m}$, resulting in a calculated power density of $34.522 \mathrm{~W} / \mathrm{gHM}$ using the active fuel geometry and the $\mathrm{UO}_{2}$ density of $10.4215 \mathrm{~g} / \mathrm{cm}^{3}$, corresponding to $95 \%$ theoretical density. The heated fuel length is $4.26 \mathrm{~m}$.

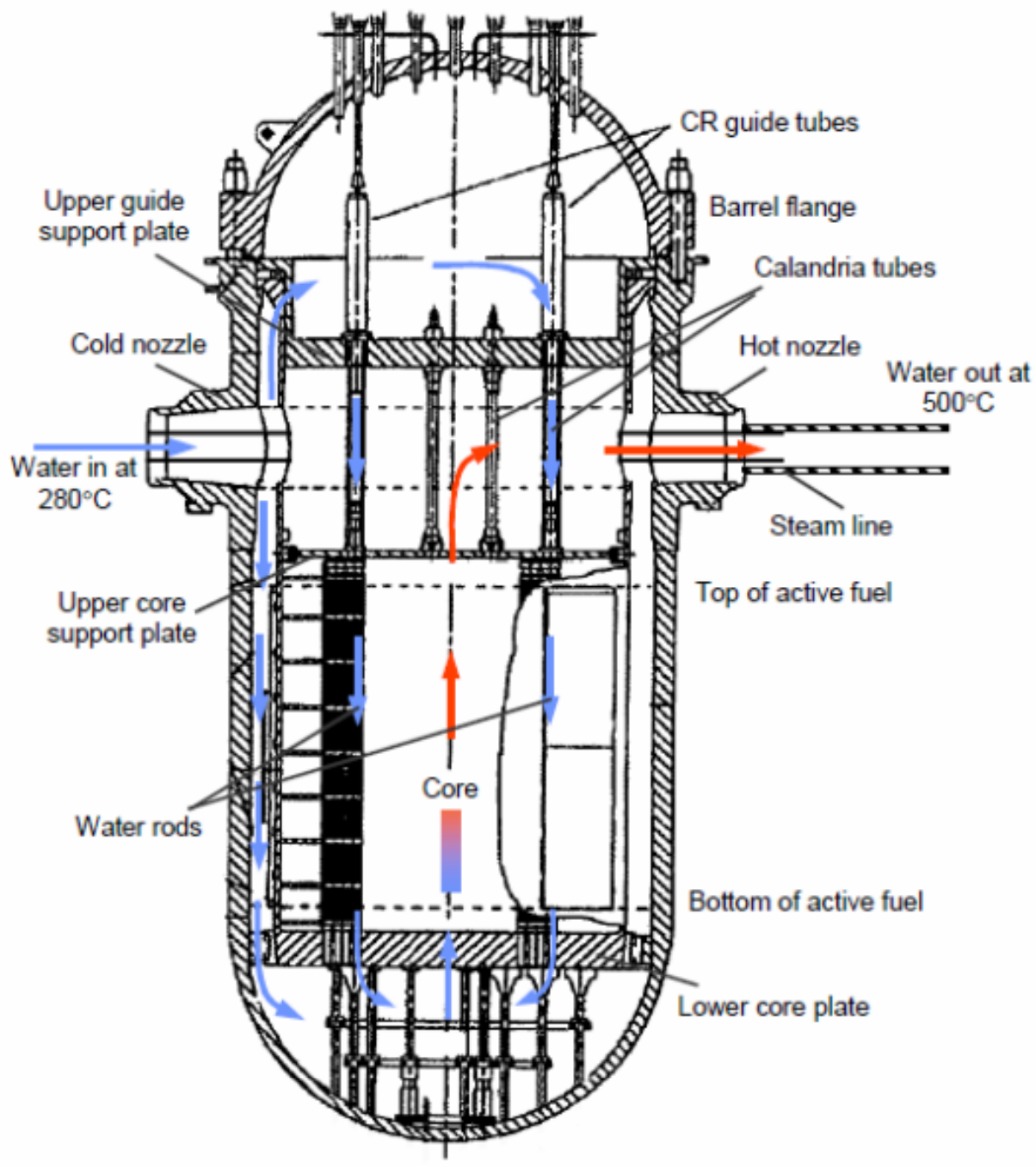

Figure 1-1. Conceptual design of the reference SCWR pressure vessel and internals, from [McDonald, 2005]. 
Table 1-1. Conceptual reference SCWR reference design power and coolant conditions. From [McDonald, 2005].

\begin{tabular}{ll}
\multicolumn{1}{c}{ Parameter } & \multicolumn{1}{c}{ Value } \\
\hline Thermal power & $3575 \mathrm{MWt}$ \\
Net electric power & $1600 \mathrm{MWe}$ \\
Net thermal & \\
efficiency & $44.8 \%$ \\
Operating pressure & $25 \mathrm{MPa}$ \\
$\begin{array}{l}\text { Reactor inlet } \\
\text { temperature }\end{array}$ & $280^{\circ} \mathrm{C}$ \\
$\begin{array}{l}\text { Reactor outlet } \\
\text { temperature }\end{array}$ & $500^{\circ} \mathrm{C}$ \\
Reactor flow rate & $1843 \mathrm{~kg} / \mathrm{s}$ \\
Plant lifetime & 60 years \\
\hline
\end{tabular}

Table 1-2. Reference reactor core design for the reference SCWR. From [McDonald, 2005].

\begin{tabular}{ll}
\hline Number of fuel assemblies & 145 \\
Equivalent diameter & $3.93 \mathrm{~m}$ \\
Core barrel inside and outside diameter & $4.3 / 4.5 \mathrm{~m}$ \\
Axial/radial/local/total peaking factor & $1.4 / 1.3 / 1.1 / 2.0$ (best estimate) \\
& $1.4 / 1.4 / 1.2 / 2.35$ (safety analysis) \\
Average power density & $69.4 \mathrm{~kW} / \mathrm{L}$ \\
Average linear power & $19.2 \mathrm{~kW} / \mathrm{m}$ \\
Peak linear power at steady-state conditions & $39 \mathrm{~kW} / \mathrm{m}$ \\
Core pressure drop & $0.15 \mathrm{MPa}$ \\
Water rod flow & $1660 \mathrm{~kg} / \mathrm{s}(90 \%$ of nominal flow rate) \\
\hline
\end{tabular}

Table 1-3. Reference fuel assembly design for the reference SCWR. From [McDonald, 2005].

\begin{tabular}{ll}
\hline Fuel pin lattice & $\begin{array}{l}\text { Square } \\
25 \times 25 \text { array }\end{array}$ \\
Number of fuel pins per assembly & 300 \\
Pitch-to-diameter ratio & 1.09804 \\
Number of water rods per assembly & 36 \\
Water rod side & $33.6 \mathrm{~mm}$ \\
Water rod wall thickness & $0.4 \mathrm{~mm}$ \\
Water rod wall materials & $\mathrm{TBD}$ \\
Number of instrumentation rods per & 1 \\
assembly & \\
Number of control rod fingers per & 12 \\
assembly & \\
Control rod material & $\mathrm{B}_{4} \mathrm{C}$ \\
Number of spacer grids & 14 \\
Assembly wall thickness & $3 \mathrm{~mm}$ \\
Assembly wall material & $\mathrm{TBD}$ \\
Assembly side & $286 \mathrm{~mm}$ \\
Inter-assembly gap & $2 \mathrm{~mm}$ \\
Assembly pitch & $288 \mathrm{~mm}$ \\
\hline
\end{tabular}




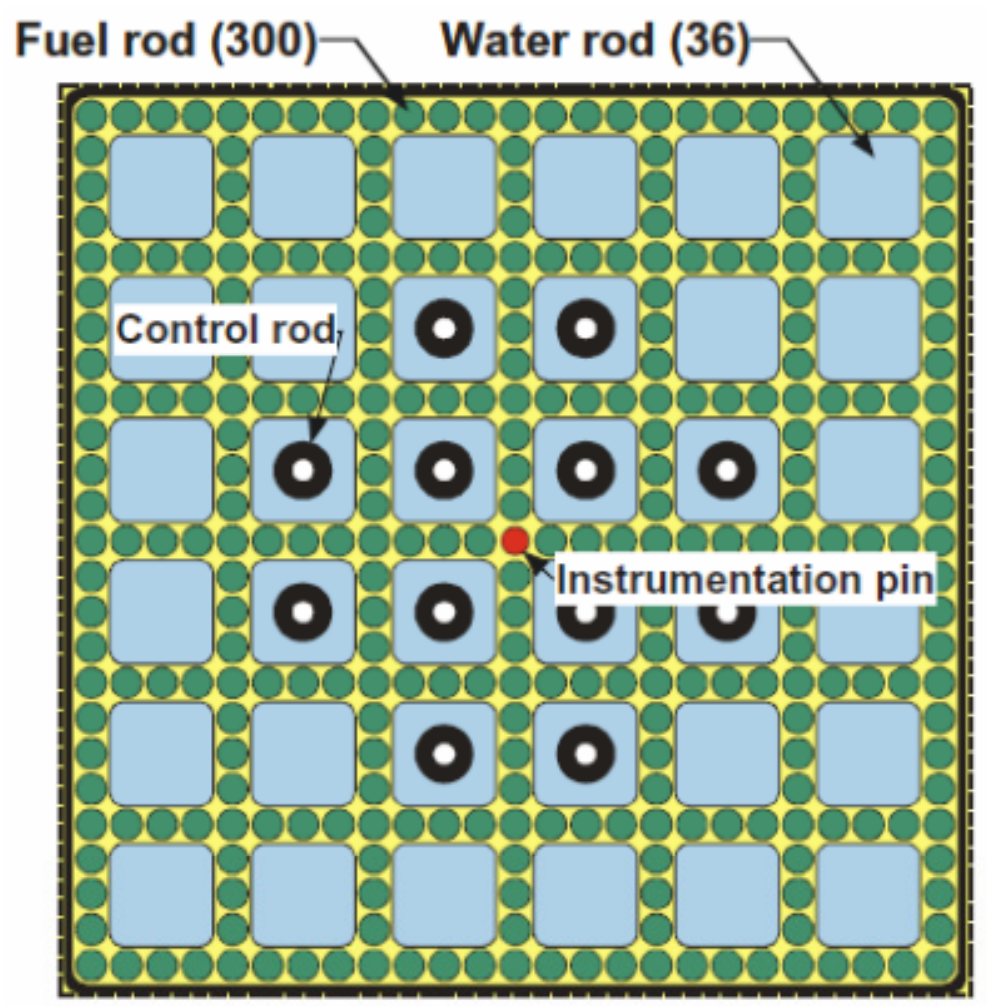

Figure 1-2. The SCWR fuel assembly with metal water rod boxes, from [McDonald, 2005].

Table 1-4. Reference fuel pin design for the reference SCWR. From [McDonald, 2005].

\begin{tabular}{ll}
\hline Fuel pin outside diameter & $10.2 \mathrm{~mm}$ \\
Fuel pin pitch & $11.2 \mathrm{~mm}$ \\
Cladding thickness & $0.63 \mathrm{~mm}$ \\
Cladding materials & $\mathrm{TBD}$ \\
Fuel pellet outside diameter & $8.78 \mathrm{~mm}$ \\
Pellet to cladding gap (cold) & 80 microns \\
Fuel composition & $\mathrm{UO}_{2}, 95 \% \mathrm{TD}$ \\
Fuel density & $10.4215 \mathrm{~g} / \mathrm{cc}$ \\
Heated fuel length & $4.27 \mathrm{~m}$ \\
Fission gas plenum length & $0.6 \mathrm{~m}$ \\
Total fuel pin height & $4.87 \mathrm{~m}$ \\
Fill gas pressure at room temperature & $6.0 \mathrm{MPa}$ \\
\hline
\end{tabular}

\subsection{Neutronic computational model used in [McDonald, 2005]}

The physics calculations in [McDonald, 2005] were performed using a $1 / 8^{\text {th }}$ assembly model with the Monte Carlo code MCNP. A radial view of the MCNP model is shown in Figure 1-3. Depletion was performed with the 1-group, zero dimensional depletion code ORIGEN-2, coupled with MCNP. 


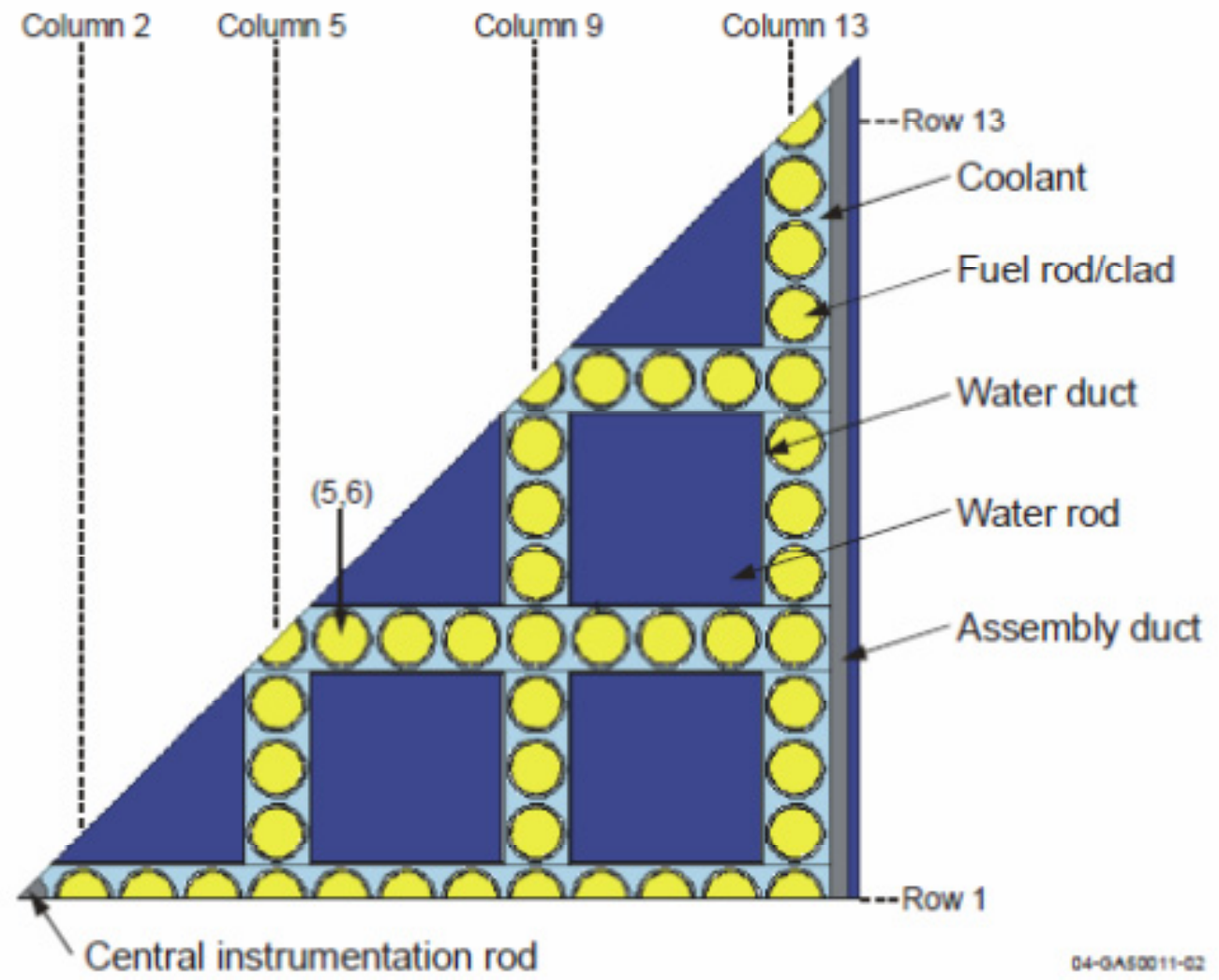

Figure 1-3. MCNP 1/8-assembly model of the $25 \times 25$ SCWR fuel assembly lattice showing the fuel rods, water rods, coolant channels.

The reference cladding material, also used for the channel boxes and for the assembly duct, is a special Oxide Dispersion Steel (ODS) known as MA956. The detailed composition of four cladding materials is shown in Table 1-5. The reason for the choice of this cladding material is not clear from [McDonald, 2005], since it appears to be a rather poor choice in terms of parasitic neutron capture (Table 1-6): it can be conjectured that the choice of MA956 could be related to superior mechanical and corrosion-resistant properties of MA956 as compared to Zr-4. A study was also reported in [McDonald, 2005] of a SCWR assembly design using $\mathrm{SiC}$ for ducts and cladding, which exhibits a substantially smaller parasitic absorption as compared to MA956. However, the SiC design was not considered "reference": for this reason, the reference design for this study is MA956-based.

The fuel rods, water channels and assembly ducts are modeled explicitly in the MCNP model. The model is divided in 10 axial zones, each featuring a different water density for the coolant and the water channels, as shown in Table 1-7.

The top reflector is modeled as containing only water at the density shown in Table 1-7, as is the bottom mixing volume. The bottom $60 \mathrm{~cm}$ long fuel gas plenum is modeled explicitly: however, it was not found in [McDonald, 2005] a detailed description of the plenum model that could be replicated exactly in our Keno-V model. The standard plenums for LWR are filled with pressurized He, and there is a spring to hold the fuel in place. However, the SCWR plenum filling is expected to be different, because of its location below the fuel, which does not appear suitable for housing a spring. For these reasons, and because the exact details of the plenum model are not expected to have a material impact on the 
neutronic properties calculated for the core, it was assumed in our model that the filling material is vacuum.

The 3 sides visible in Figure 1-3 have reflective boundary conditions, so as to model a radially infinite lattice of identical assemblies.

The water temperatures of the coolant and of the water channels are set at $527^{\circ} \mathrm{C}$ and the temperature of the fuel is set everywhere at $608^{\circ} \mathrm{C}$, because of the availability of the cross sections at these temperatures in the MCNP libraries.

Table 1-5. Major elemental constituents for MA956, Alloy 718, Zircaloy-4, and SiC. From [McDonald, 2005].

\begin{tabular}{llccc} 
Element & $\begin{array}{c}\text { MA956 } \\
(\mathrm{Wt} \%)\end{array}$ & $\begin{array}{c}\text { Alloy } 718 \\
(\mathrm{Wt} \%)\end{array}$ & $\begin{array}{c}\mathrm{Zr}-4 \\
(\mathrm{Wt} \%)\end{array}$ & $\begin{array}{c}\mathrm{SiC} \\
(\mathrm{Wt} \%)\end{array}$ \\
\hline $\mathrm{C}$ & & 0.038 & 0.027 & 30.0 \\
$\mathrm{O}$ & 0.1488 & & 0.120 & \\
$\mathrm{Al}$ & 5.75 & 0.49 & & \\
$\mathrm{Si}$ & & 0.19 & & 70.0 \\
$\mathrm{Ti}$ & 0.60 & 0.91 & & \\
$\mathrm{~V}$ & & 0.01 & & \\
$\mathrm{Cr}$ & 21.5 & 19.08 & 0.10 & \\
$\mathrm{Mn}$ & & 0.20 & & \\
$\mathrm{Fe}$ & 71.45 & 18.122 & 0.21 & \\
$\mathrm{Ni}$ & & 52.90 & 0.007 & \\
$\mathrm{Y}$ & 0.5512 & & & \\
$\mathrm{Zr}$ & & & 98.057 & \\
$\mathrm{Nb}$ & & 5.05 & 0.012 & \\
$\mathrm{Mo}$ & & 3.01 & & \\
$\mathrm{Sn}$ & & & 1.45 & \\
Density $(\mathrm{g} / \mathrm{cc})$ & 7.25 & 8.19 & 6.57 & 2.9749 \\
\hline
\end{tabular}

Table 1-6. Assembly lattice k-infinity for four different clad materials. From [McDonald, 2005].

\section{Clad Material}

\begin{tabular}{l} 
Zircaloy-4 \\
MA956 (ODS) \\
Alloy 718 \\
SiC \\
\hline
\end{tabular}

K-infinity

$\begin{array}{ll}1.425477(0.0002) & -- \\ 1.266155(0.0002) & -13.58 \\ 1.153701(0.0002) & -25.42 \\ 1.436039(0.0002) & +0.79\end{array}$

Numbers in parentheses are the one-sigma statistical relative error.

Table 1-7 shows the converged water densities at BOL used in [McDonald, 2005]. It is noted that the coolant density decreases in going from the bottom to the top of the core from $0.54732 \mathrm{~g} / \mathrm{cm}^{3}$ at the entrance of the active core region to $0.09171 \mathrm{~g} / \mathrm{cm}^{3}$ at the exit of the upper plenum. The water density in the moderator water rods increases in going from the bottom of the core to the top, since it flows in the opposite direction as compared to the coolant. The axial profile of the fuel enrichment was chosen in [McDonald, 2005] to avoid a skewed axial power density, that would have been obtained if a uniform $5 \%$ enrichment was chosen instead (see Figure 1-4). This seem to suggest that the moderation could be 
reduced in the top part of the core, thus reducing the size of the water rods and leaving more room available for active power generation, thus potentially improving the economic performance of this design.

Table 1-7. Converged beginning-of-life SCWR water densities for the coolant. From [McDonald, 2005].

\begin{tabular}{lccccc}
\hline \multicolumn{1}{c}{ Region } & $\begin{array}{c}\text { Lower } \\
\text { Elevation } \\
(\mathrm{cm})\end{array}$ & $\begin{array}{c}\text { Upper Elevation } \\
(\mathrm{cm})\end{array}$ & $\begin{array}{c}\text { Coolant } \\
\text { Density } \\
(\mathrm{g} / \mathrm{cc})\end{array}$ & $\begin{array}{c}\text { Water Rod } \\
\text { Density } \\
(\mathrm{g} / \mathrm{cc})\end{array}$ & $\begin{array}{c}\mathrm{UO}_{2} \text { Enrich } \\
\left(\mathrm{wt} \%{ }^{235} \mathrm{U}\right)\end{array}$ \\
\hline $\begin{array}{l}\text { Lower mixing or } \\
\text { reflector }\end{array}$ & -90.48 & -60.00 & 0.5649 & 0.5379 & \\
Gas plenum & -60.00 & 0.00 & 0.5629 & 0.5363 & \\
Fuel (bottom) & 0.00 & 42.7 & 0.54732 & 0.5345 & 5.0 \\
Fuel & 42.7 & 85.4 & 0.49647 & 0.5375 & 5.0 \\
Fuel & 85.4 & 128.1 & 0.40936 & 0.5468 & 5.0 \\
Fuel & 128.1 & 170.8 & 0.30866 & 0.5608 & 5.0 \\
Fuel & 170.8 & 213.5 & 0.22573 & 0.5796 & 5.0 \\
Fuel & 213.5 & 256.2 & 0.17009 & 0.6044 & 5.0 \\
Fuel & 256.2 & 298.9 & 0.13481 & 0.6336 & 4.9 \\
Fuel & 298.9 & 341.6 & 0.11265 & 0.6683 & 4.8 \\
Fuel & 341.6 & 384.3 & 0.09918 & 0.7056 & 4.8 \\
Fuel (top) & 384.3 & 427.0 & 0.09200 & 0.7427 & 4.8 \\
Upper reflector & 427.0 & 457.48 & 0.09171 & 0.7779 & \\
\hline
\end{tabular}

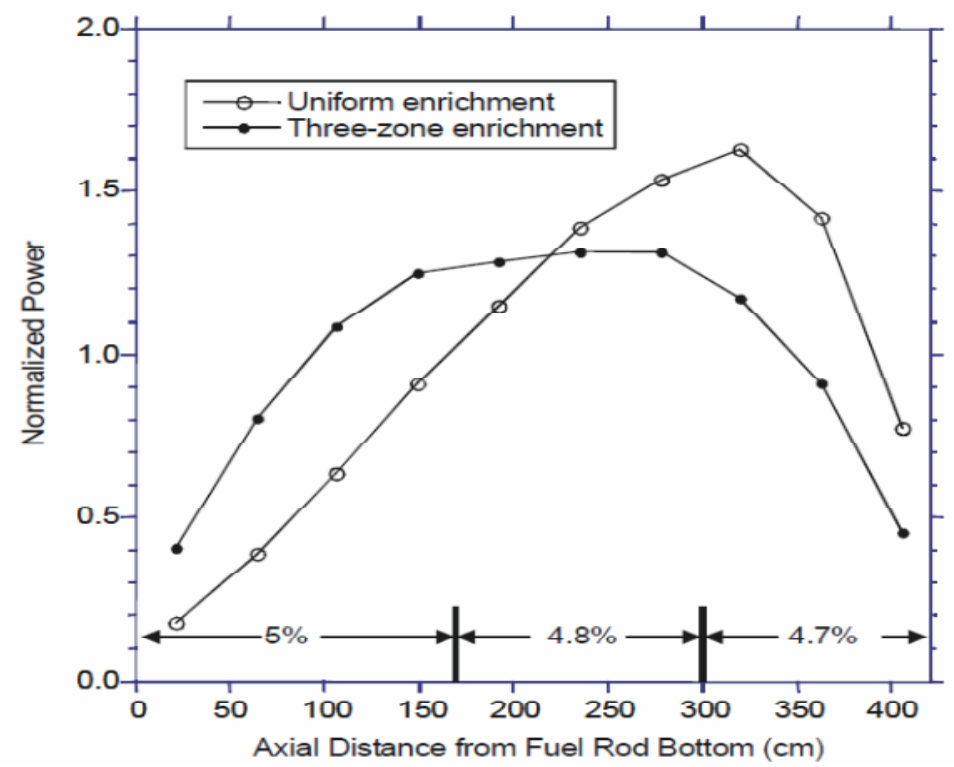

Figure 1-4. Axial power from [McDonald, 2005]. 


\section{Description of the model}

The full input of the TRITON/Keno-V is shown in Appendix A. To maximize the computational accuracy, a full assembly three-dimensional model has been modeled with the well benchmarked Monte Carlo code Keno-V. A radial view of the assembly model is shown in Figure 2-1: it is observed that all the fuel rods are modeled explicitly, including the fuel-cladding gap at nominal conditions. The assembly shroud and the interbundle gap are also explicitly modeled. The central instrumentation channels are occupied by water during the depletion analysis.

The active fuel region is divided in 10 zones of equal length $(42.7 \mathrm{~cm})$, consistently with the data in Table 1-7. The water densities of each coolant and moderator zones are shown in Figure 1-7, and are kept constant throughout the depletion analysis. For simplicity, the water channel ducts are not modeled explicitly, but the duct material is homogenized with the water in the channels. Since the self shielding effect of the duct materials is negligible, the homogenized model does provide an accurate representation of the system from a neutronic perspective. Since the wall channels take $4.71 \%$ of the volume of the water channels, the water density of Table 1-7 is reduced to $95.29 \%$ of the nominal value, while the remaining space is occupied by the isotopes of the ducts. Because of the large parasitic absorption of MA956 as compared to standard Zircaloy-4 (see Table 1-6 for the $\mathrm{k}_{\text {inf }}$ calculated at BOL using the MCNP model of [McDonald, 2005]), the composition of the cladding is accurately reproduced in the model used for this analysis.]

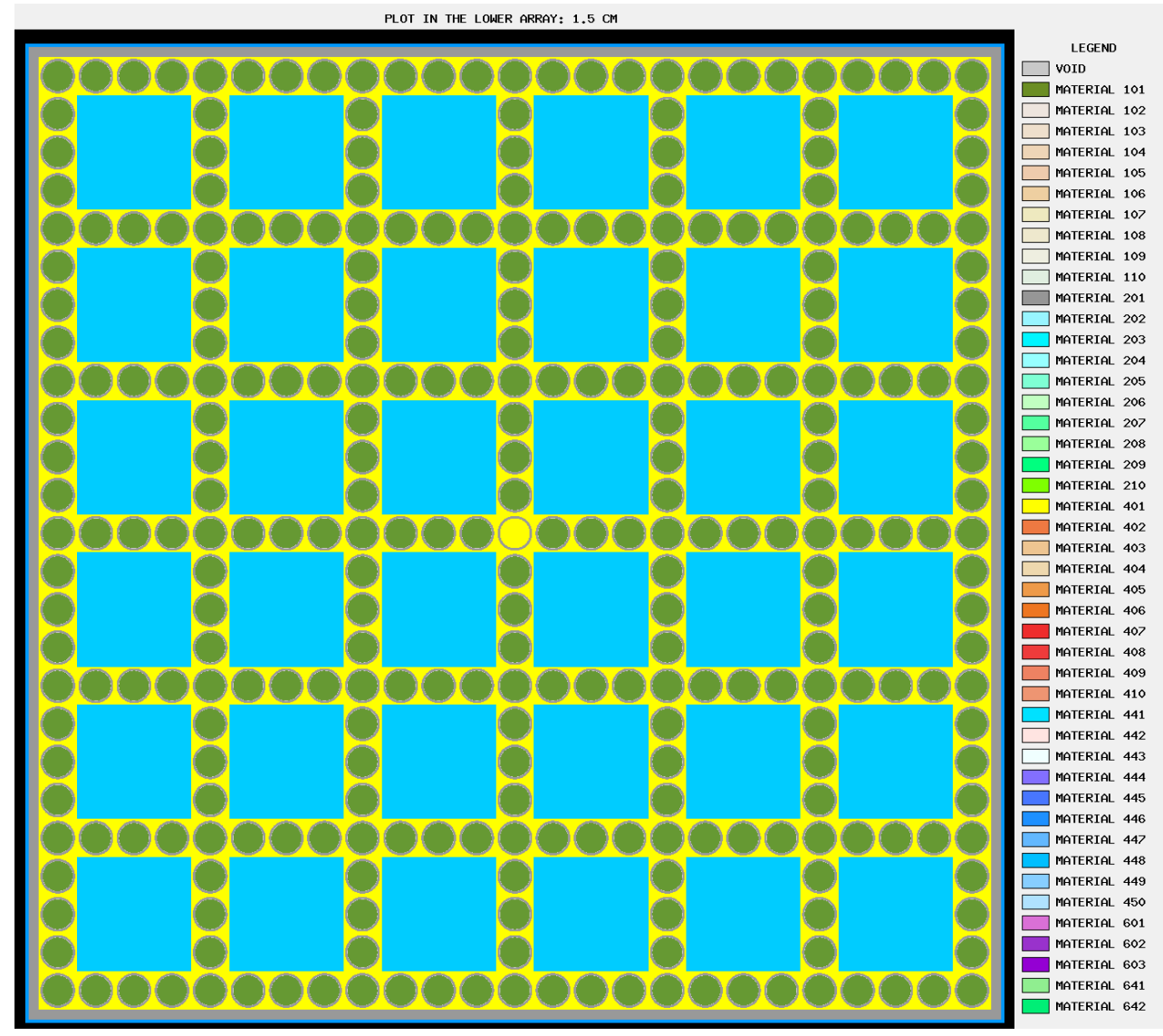

Figure 2-1. Radial view of the Keno-V full assembly model used for this work. 
No information was found in [McDonald, 2005] on the water conditions in the inter-assembly gaps, which are $1 \mathrm{~mm}$ thick on each side of the assembly in Table 1-3. In fact, considerable uncertainties still are present in the final design and the numbers in Table 1-3 appear to be only tentative: “... a number of the dimensions are tentative, including the fuel bundle wall thickness, and the inter-assembly gap size and the fuel pin spacer have yet to be designed" [McDonald, 2005]. For simplicity, the water density in the inter-assembly gaps is assumed at the density of zone 6 , or $0.5760 \mathrm{~g} / \mathrm{cm}^{3}$, since it is close to the average of the axial density of the water channels. The neutronic effect of the water in the interassembly gap is expected to be minimal.

The $\mathrm{UO}_{2}$ density is $10.4215 \mathrm{~g} / \mathrm{cm}^{3}$ as shown in Table 1-4. The fuel and water temperatures were set at $608^{\circ} \mathrm{C}$ and $527^{\circ} \mathrm{C}$ to match the parameters of the MCNP model of [McDonald, 2005] (see Section 1.1).

The bottom and top reflectors are modeled explicitly with the parameters indicated in Table 1-7. The density of the water in the water channels has been reduced to $95.29 \%$ of the nominal values shown in Figure 1-7, to allow the homogenization of the water channels ducts, as was done in the active fuel region. This allows an explicit modeling of the water channel ducts, even though the neutronic importance of structural materials in those regions is minimal. The boundary conditions above the upper reflectors and below the lower mixing or reflectors are void. The bottom $60 \mathrm{~cm}$ long fuel gas plenum is modeled explicitly with a tube representing the fuel-gas plenum, surrounded by water at the appropriate density.

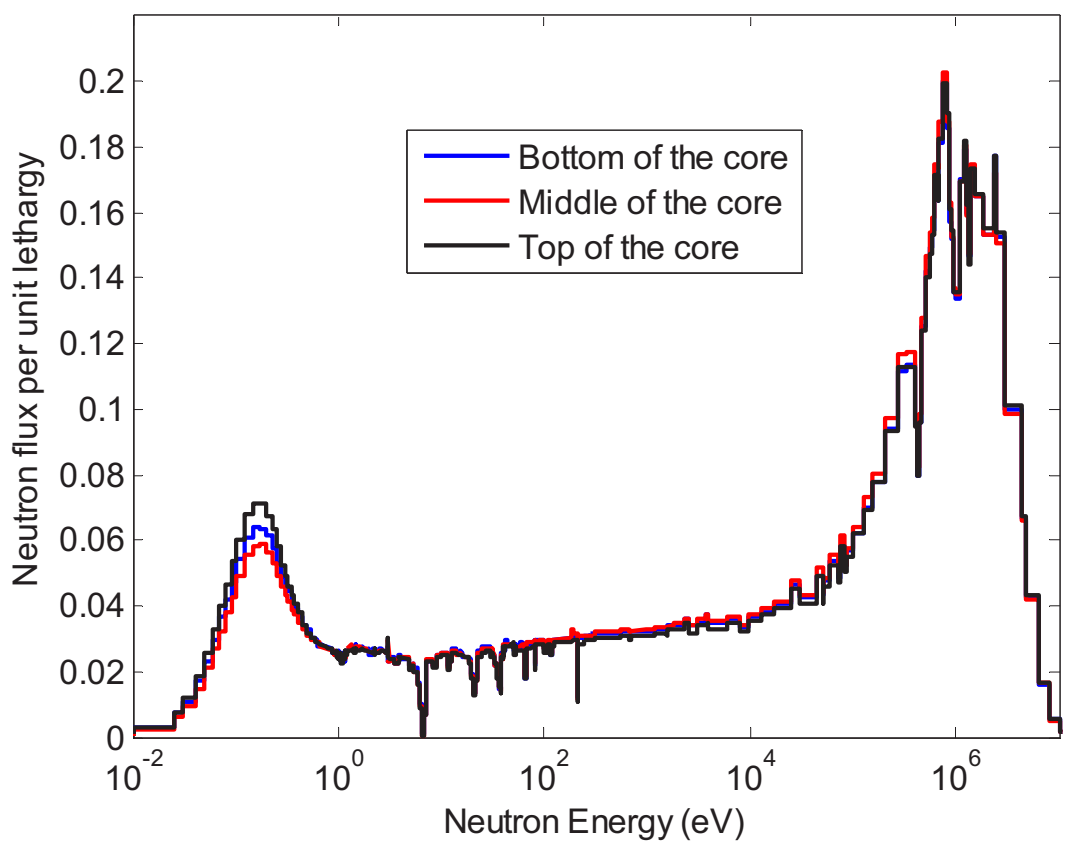

Figure 2-2. SCWR spectra at BOL in the fuel at the bottom, center and top of the core.

The depletion analysis was performed using both "Nitawl and ENDF/B-V" and "CENTRM and ENDF/B-VII" for the multigroup cross section generation. Because of the thermal spectrum of this core (see Figure 2-3), no substantial difference was observed between the results of the two cross section processing (see Figure 2-2 for a comparison of the $\mathrm{k}_{\mathrm{eff}}$ evolution with burnup using the two cross section processing method). The ORIGEN-S depletion calculations are terminated at 49 GWD/MTiHM, since the single batch burnup $\left(\mathrm{BU}_{1}\right)$ is crossing 1 at $32.7 \mathrm{GWD} / \mathrm{MTiHM}$. The actual burnup reached using a 3batches shuffling scheme can be calculated approximately using the linear reactivity model: Equation 2.1 
shows the burnup burnup " $B U_{n}$ " that would be obtained using an " $n$-batches" reshuffling scheme. Assuming that the SCWR would be operated on a 3-batches reshuffling, $\mathrm{BU}_{3}$ would be equal to 49 GWD/MTiHM, or 3.894 EFPY at the nominal power density.

$\mathrm{BU}_{\mathrm{n}}=\mathrm{BU}_{1} \cdot 2 \mathrm{n} /(\mathrm{n}+1) \quad$ Eq. $2-1$

The calculated axial power profile for the reference assembly is plotted in Figure 2-4, and is in good agreement with that indicated as "Three-zone enrichment" in Figure 1-4 from [McDonald, 2005].

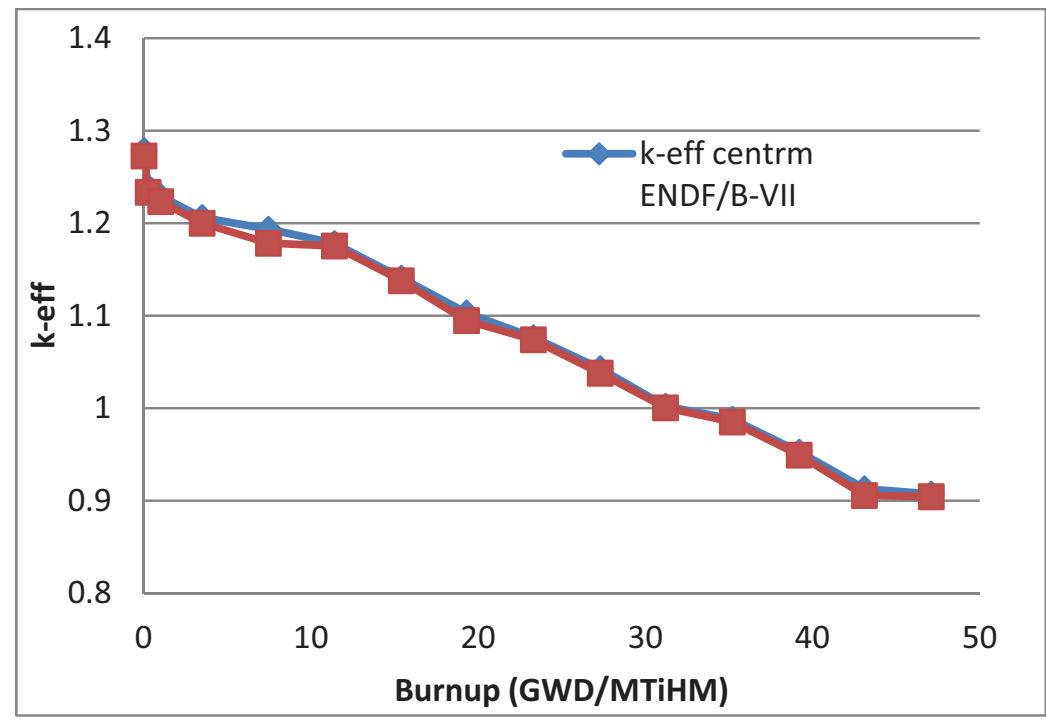

Figure 2-3. Evolution with burnup of the radially-reflected burnup, using both "Nitawl and ENDF/B-V" and "CENTRM and ENDF/B-VII" for the multigroup cross section generation.

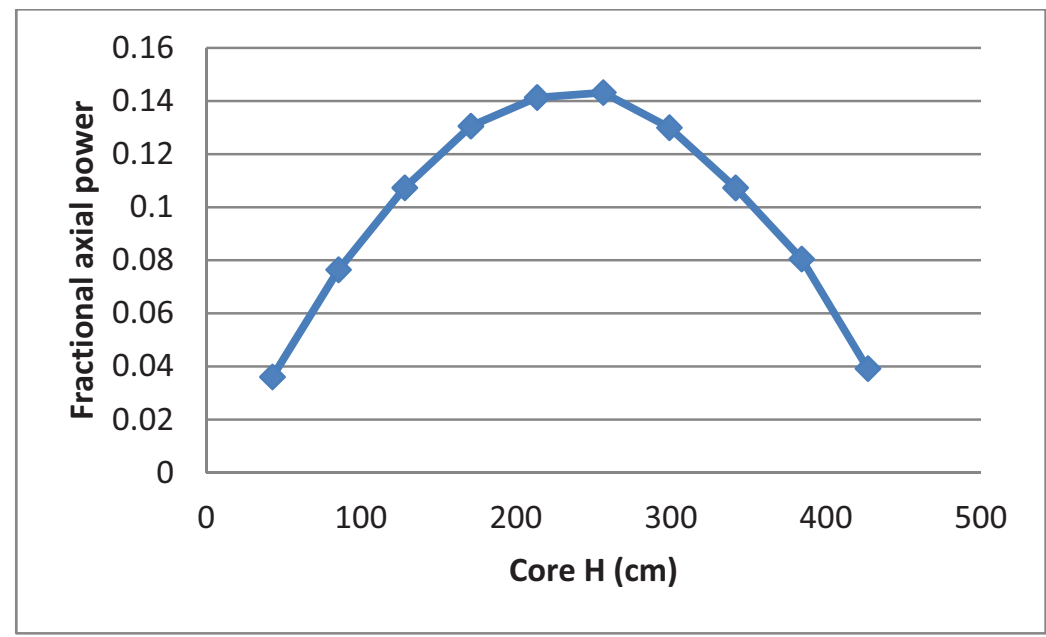

Figure 2-4. Axial power calculated by the Keno V model, to be compared to the axial power profile indicated as "Three-zone enrichment" in Figure 1-4 from [McDonald, 2005]. 


\section{REFERENCES}

McDonald2005 Philip MacDonald, Jacopo Buongiorno,James W. Sterbentz, Cliff Davis, Robert Witt, Prof. Gary Was, J. McKinley, S. Teysseyre, Luca Oriani, Vefa Kucukboyaci, Lawrence Conway, N. Jonsson, Bin Liu, "Feasibility Study of Supercritical Light Water Cooled Reactors for Electric Power Production,” INEEL/EXT-04-02530, January 2005.

Piet2011 Steven J. Piet, Samuel E. Bays, David W. Gerts, Edward A. Hoffman, "Description of Transmutation Library for Fuel Cycle System Analyses (FY2011 update)," FCRDSYSA-2010-000116, Rev1, INL/EXT-10-19545, Rev1, September 16, 2011. 


\section{APPENDIX A}

\section{TRITON/KENO-V input for the RBWR model}

The TRITON/Keno-V model used for the reference depletion calculation is shown in this appendix. The Keno $\mathrm{V}$ execution with the number of neutrons specified in this input required a CPU time of approximately 10 minutes on a single Intel E8400@3GHz processor. The k-eff is calculated with a standard deviation of approximately $20 \mathrm{pcm}$. The attached input has been executed on SCALE5.1 and SCALE6.1, using both "nitawl and ENDF/B-V" and "centrm and ENDF/B-VII". No substantial difference was observed in the calculated results using the two codes and cross section processing methods (see Figure 2-3). For this reason, the results using nitawl and ENDF/B-V were chosen for further processing, since they could be obtained using SCALE5.1. The author has used SCALE5.1 extensively in the past, and has better confidence in his understanding of the printed output, normalization factors etc... as compared to the just-released SCALE6.1

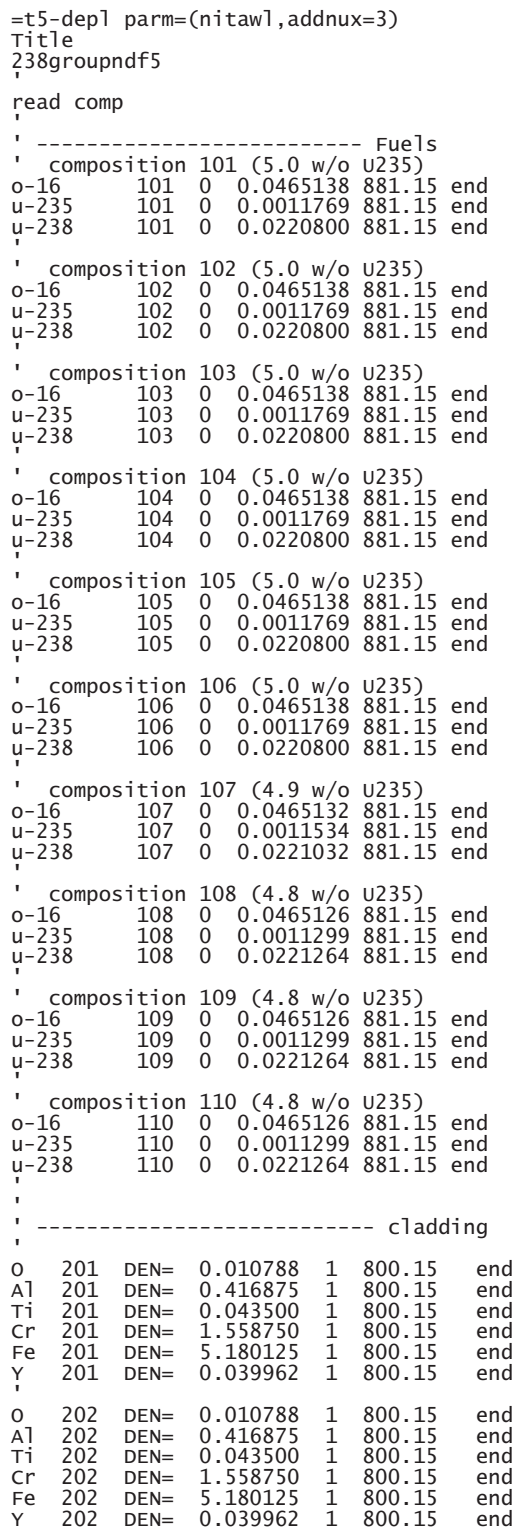




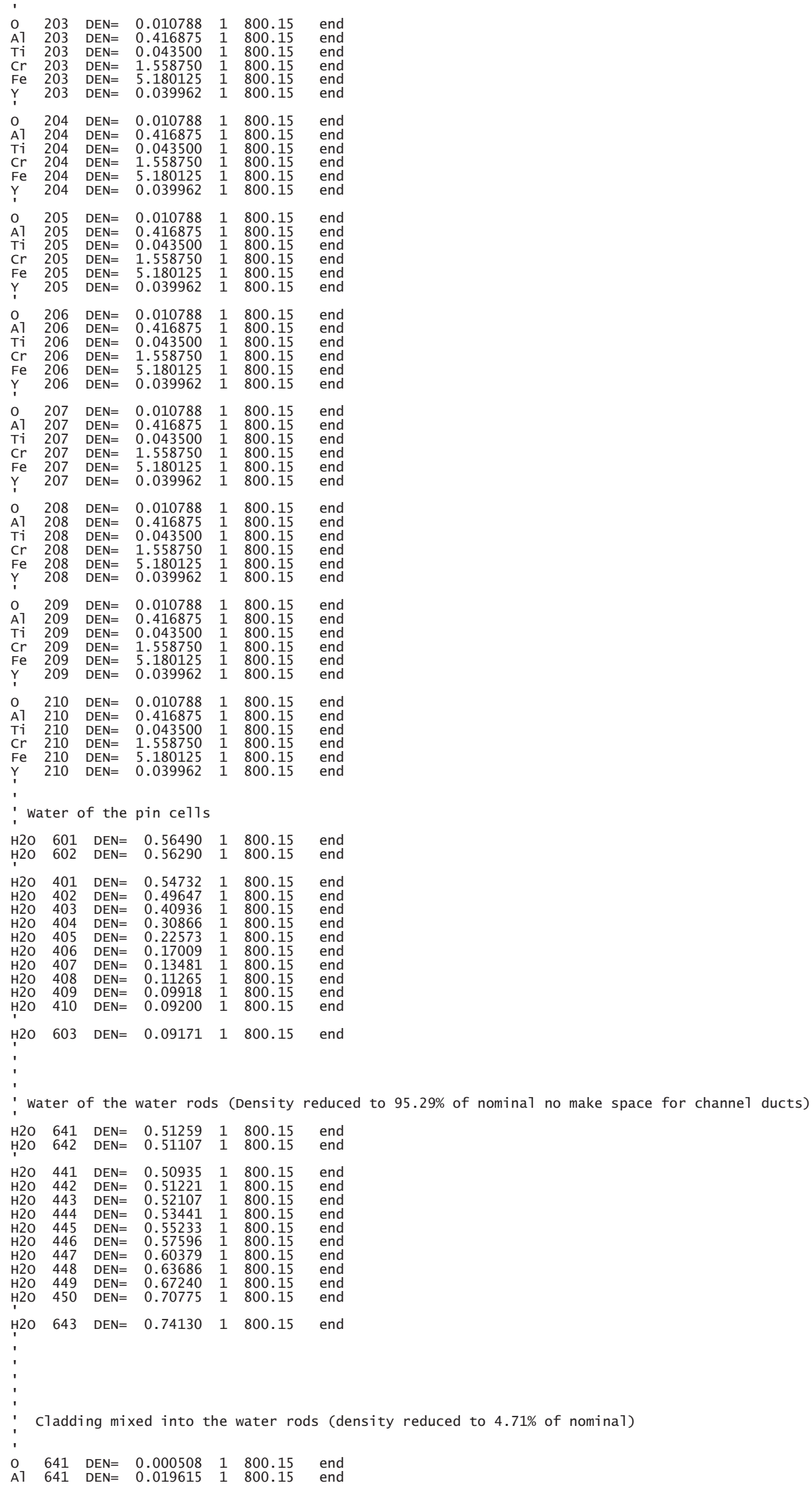




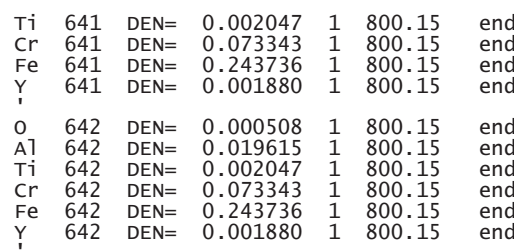

;

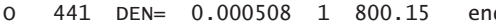

A1 441 DEN $=0.019615 \quad 1 \quad 800.15$ end

$\mathrm{Ti} \quad 441$ DEN $=0.002047 \quad 1 \quad 800.15$ end

Fe 441 DEN $=0.243736$ 1 800.15 end

$Y \quad 441 \mathrm{DEN}=0.001880100 .15$ end

0442 DEN $=0.000508 \quad 1 \quad 800.15$ end

A1 442 DEN $=0.019615 \quad 1 \quad 800.15$ end

$\begin{array}{llllll}\mathrm{Ti} & 442 & \mathrm{DEN}= & 0.002047 & 1 & 800.15\end{array}$ end

$\mathrm{Fe} 442 \mathrm{DEN}=0.243736 \quad 1 \quad 800.15$ end

$Y \quad 442 \mathrm{DEN}=0.001880100 .15$ end

O 443 DEN $=0.000508 \quad 1 \quad 800.15$ end

A1 443 DEN $=0.019615$ 1 800.15 end

Ti 443 DEN $=\begin{array}{llll}0.002047 & 1 & 800.15 & \text { end }\end{array}$

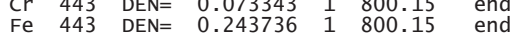

$Y \quad 443$ DEN $=0.001880 \quad 1 \quad 800.15$ end

0444 DEN $=0.000508 \quad 1 \quad 800.15$ end

A1 444 DEN $=0.019615 \quad 1 \quad 800.15$ end

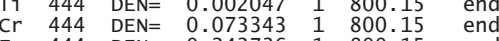

Fe 444 DEN $=0.243736 \quad 1 \quad 800.15$ end

Y 444 DEN $=0.001880100 .15$ end

$\begin{array}{lllllll}0 & 445 & \text { DEN }= & 0.000508 & 1 & 800.15 & \text { end }\end{array}$

A1 445 DEN $=0.019615$ 1 0.800 .15 end

Cr 445 DEN $=0.073343 \quad 1 \quad 800.15$ end

$\begin{array}{lllllll}\mathrm{Fe} & 445 & \mathrm{DEN}= & 0.243736 & 1 & 800.15 & \text { end } \\ \mathrm{Y} & 445 & \mathrm{DEN}= & 0.001880 & 1 & 800.15 & \text { end }\end{array}$

0446 DEN $=0.000508 \quad 1 \quad 800.15$ end

A1 446 DEN $=0.019615$ 1 800.15 end

Ti 446 DEN $=0.002047 \quad 1 \quad 800.15$ end

$\mathrm{Cr} 446$ DEN $=0.073343 \quad 1 \quad 800.15$ end

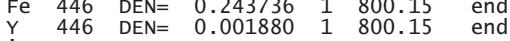

0447 DEN $=0.000508 \quad 1 \quad 800.15$ end

A1 447 DEN $=0.019615 \quad 1 \quad 800.15$ end

T1 447 DEN $=0.002047 \quad 1 \quad 800.15$ end

$\mathrm{Cr} 447 \mathrm{DEN}=0.0733436100 .15$ end

$\begin{array}{lllllll}\mathrm{F} & 447 & \mathrm{DEN}= & 0.243736 & 1 & 800.15 & \text { end } \\ \mathrm{Y} & \mathrm{DEN}= & 0.001880 & 1 & 800.15 & \text { end }\end{array}$

O 448 DEN $=0.000508 \quad 1 \quad 800.15$ end

AT 448 DEN $=0.019615 \quad 1 \quad 800.15$ end

Cr 448 DEN $=0.073343$ 1 800.15 end

$\mathrm{Fe} \quad 448$ DEN $=0.243736 \quad 1 \quad 800.15$

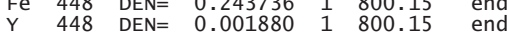

$\begin{array}{llllll}0 & 449 & \mathrm{DEN}= & 0.000508 & 1 & 800.15\end{array}$ end

A1 449 DEN $=0.019615 \quad 1 \quad 800.15$ end

Ti 449 DEN $=0.002047$ 1 800.15 end

$\mathrm{Cr} 449$ DEN $=0.073343 \quad 1 \quad 800.15$ end

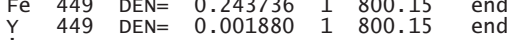

O 450 DEN $=0.000508 \quad 1 \quad 800.15$ end

A] 450 DEN $=0.019615 \quad 1 \quad 800.15$ end

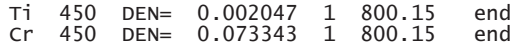

$\mathrm{Fe} 450$ DEN $=\begin{array}{llll}0.243736 & 1 & 800.15 & \text { end }\end{array}$

$Y \quad 450$ DEN $=0.001880 \quad 1 \quad 800.15$ end

,

0 643 DEN $=0.000508 \quad 1 \quad 800.15$

A1 643 DEN $=0.000508 \quad 1 \quad 800.15$ end

Ti 643 DEN $=0.002047 \quad 1 \quad 800.15$ end

$\mathrm{Cr} 643$ DEN $=0.073343 \quad 1 \quad 800.15$ end

$\mathrm{Y} 643 \mathrm{DEN}=0.001880 \quad 1 \quad 800.15$ end

1

end comp

,

read cel1data

latticece 11 triangpitch fuel $r=0.439101$ latticece11 triangpitch fuel $r=0.439102$

cladr $=0.5100201$ cladr=0.5100 202 pitch=1.120 402

end 


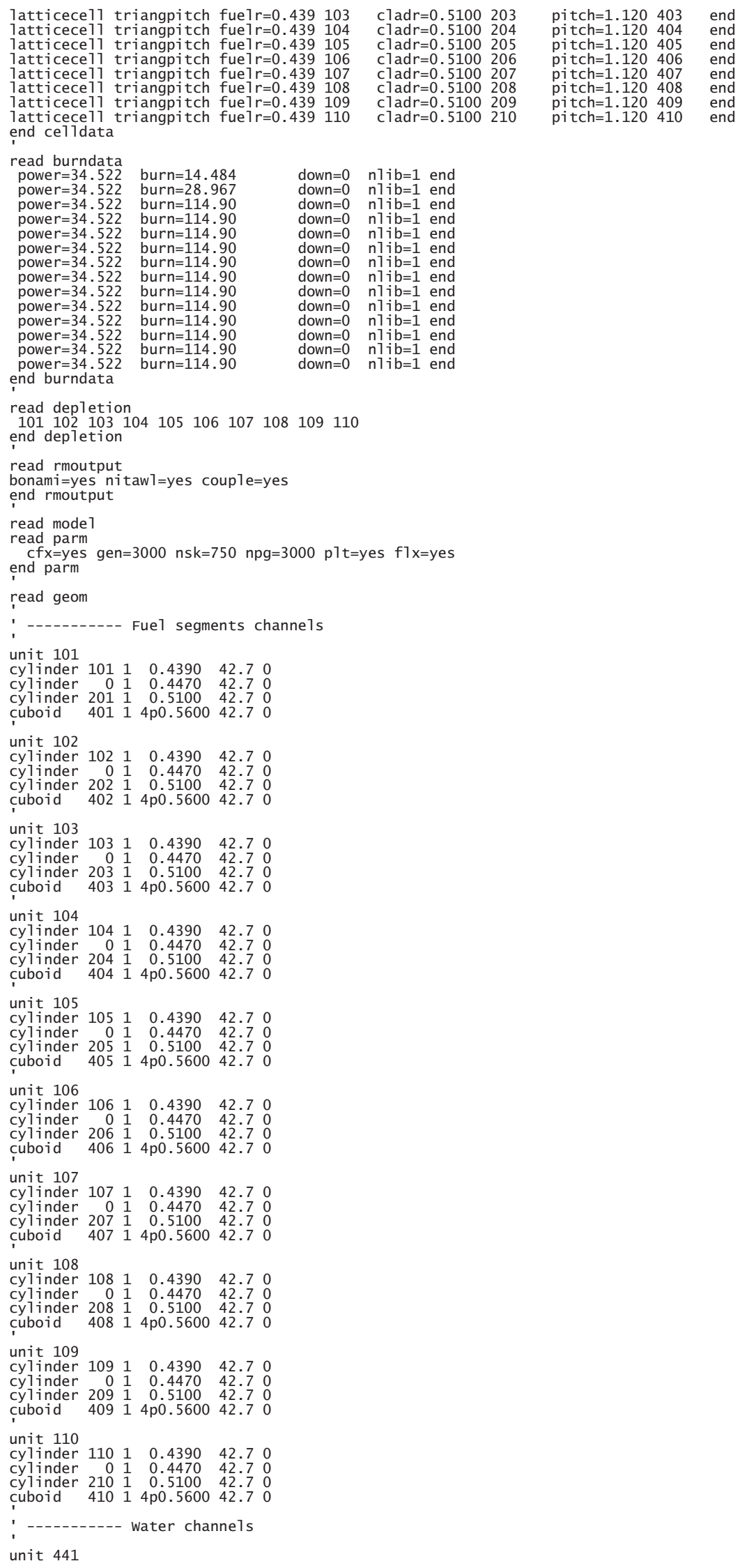




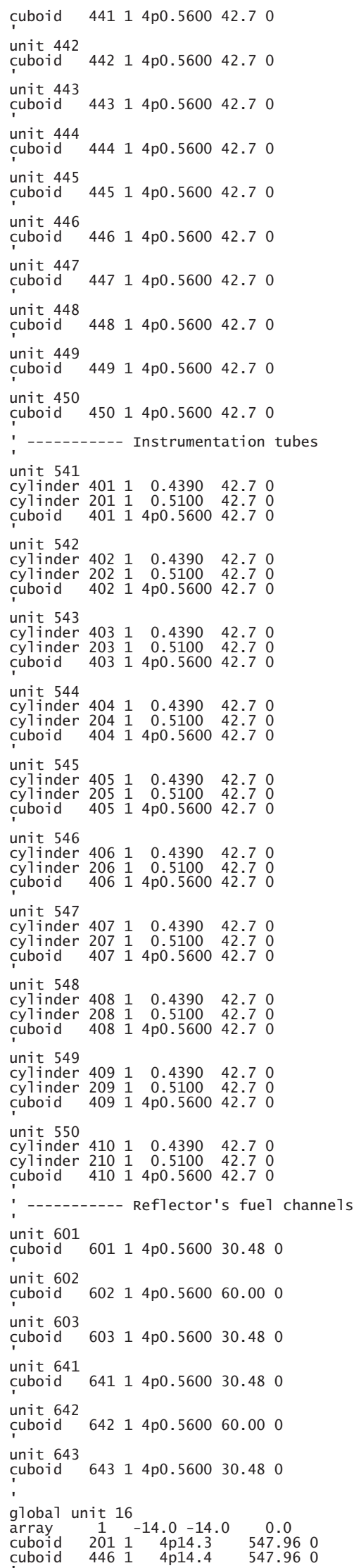


end geom
READ ARRAY ARA $=1$ NUX=25 NUY=25 NUZ=13 FILL

' 601601 mixing region (just water)

601601601601601601601601601601601601601601601601601601601601601601601601601

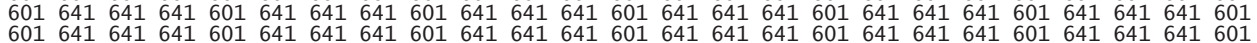
$\begin{array}{llllllllllllllllllllllllllll}601 & 641 & 641 & 641 & 601 & 641 & 641 & 641 & 601 & 641 & 641 & 641 & 601 & 641 & 641 & 641 & 601 & 641 & 641 & 641 & 601 & 641 & 641 & 641 & 601 \\ 04\end{array}$

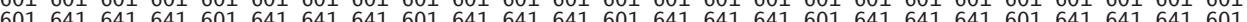
$\begin{array}{lllllllllllllllllllllllllllll}601 & 641 & 641 & 641 & 601 & 641 & 641 & 641 & 601 & 641 & 641 & 641 & 601 & 641 & 641 & 641 & 601 & 641 & 641 & 641 & 601 & 641 & 641 & 641 & 601\end{array}$ $\begin{array}{lllllllllllllllllllllllll}601 & 641 & 641 & 641 & 601 & 641 & 641 & 641 & 601 & 641 & 641 & 641 & 601 & 641 & 641 & 641 & 601 & 641 & 641 & 641 & 601 & 641 & 641 & 641 & 601\end{array}$ 601641641641601641641641601641641641601641641641601641641641601641641641601

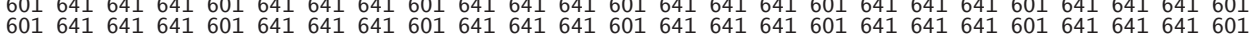
$\begin{array}{lllllllllllllllllllllllllll}601 & 641 & 641 & 641 & 601 & 641 & 641 & 641 & 601 & 641 & 641 & 641 & 601 & 641 & 641 & 641 & 601 & 641 & 641 & 641 & 601 & 641 & 641 & 641 & 601\end{array}$ $\begin{array}{lllllllllllllllllllllllll}601 & 601 & 601 & 601 & 601 & 601 & 601 & 601 & 601 & 601 & 601 & 601 & 601 & 601 & 601 & 601 & 601 & 601 & 601 & 601 & 601 & 601 & 601 & 601 & 601 \\ 601 & 641 & 641 & 641 & 601 & 641 & 641 & 641 & 601 & 641 & 641 & 641 & 601 & 641 & 641 & 641 & 601 & 641 & 641 & 641 & 601 & 641 & 641 & 641 & 601\end{array}$ $\begin{array}{llllllllllllllllllllllllllll}601 & 641 & 641 & 641 & 601 & 641 & 641 & 641 & 601 & 641 & 641 & 641 & 601 & 641 & 641 & 641 & 601 & 641 & 641 & 641 & 601 & 641 & 641 & 641 & 601\end{array}$ $\begin{array}{lllllllllllllllllllllllll}601 & 641 & 641 & 641 & 601 & 641 & 641 & 641 & 601 & 641 & 641 & 641 & 601 & 641 & 641 & 641 & 601 & 641 & 641 & 641 & 601 & 641 & 641 & 641 & 601\end{array}$ 601641641641601641641641601641641641601641641641601641641641601641641641601 $\begin{array}{llllllllllllllllllllllllllll}601 & 641 & 641 & 641 & 601 & 641 & 641 & 641 & 601 & 641 & 641 & 641 & 601 & 641 & 641 & 641 & 601 & 641 & 641 & 641 & 601 & 641 & 641 & 641 & 601\end{array}$

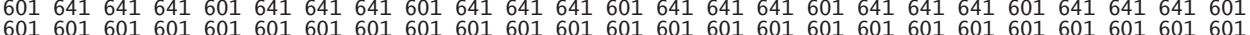
$\begin{array}{lllllllllllllllllllllllll}601 & 641 & 641 & 641 & 601 & 641 & 641 & 641 & 601 & 641 & 641 & 641 & 601 & 641 & 641 & 641 & 601 & 641 & 641 & 641 & 601 & 641 & 641 & 641 & 601 \\ 601 & 641 & 641 & 641 & 601 & 641 & 641 & 641 & 601 & 641 & 641 & 641 & 601 & 641 & 641 & 641 & 601 & 641 & 641 & 641 & 601 & 641 & 641 & 641 & 601\end{array}$

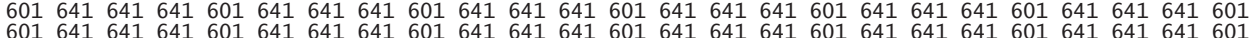

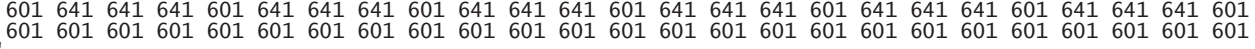
Lower Fission gas plenum

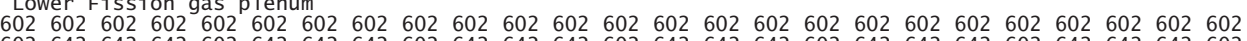
$\begin{array}{lllllllllllllllllllllllll}602 & 642 & 642 & 642 & 602 & 642 & 642 & 642 & 602 & 642 & 642 & 642 & 602 & 642 & 642 & 642 & 602 & 642 & 642 & 642 & 602 & 642 & 642 & 642 & 602\end{array}$

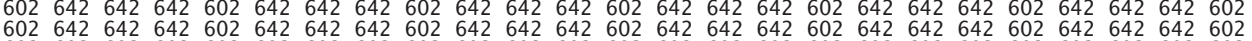

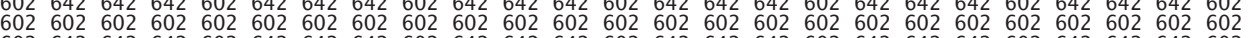
$\begin{array}{lllllllllllllllllllllllll}602 & 642 & 642 & 642 & 602 & 642 & 642 & 642 & 602 & 642 & 642 & 642 & 602 & 642 & 642 & 642 & 602 & 642 & 642 & 642 & 602 & 642 & 642 & 642 & 602\end{array}$

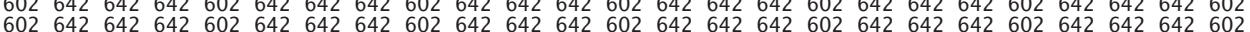

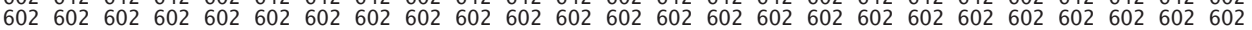

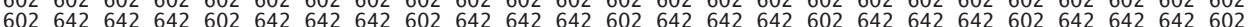

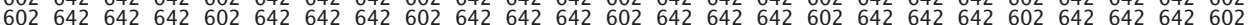

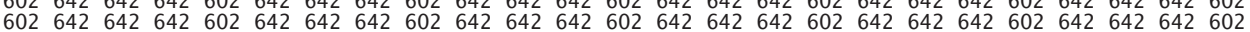
$602602602602602602 \quad 602602 \quad 602602602602602602602602602602602602602602602642602$

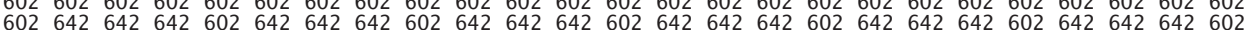
$\begin{array}{lllllllllllllllllllllllllll}602 & 642 & 642 & 642 & 602 & 642 & 642 & 642 & 602 & 642 & 642 & 642 & 602 & 642 & 642 & 642 & 602 & 642 & 642 & 642 & 602 & 642 & 642 & 642 & 602\end{array}$ $\begin{array}{lllllllllllllllllllllllll}602 & 642 & 642 & 642 & 602 & 642 & 642 & 642 & 602 & 642 & 642 & 642 & 602 & 642 & 642 & 642 & 602 & 642 & 642 & 642 & 602 & 642 & 642 & 642 & 602\end{array}$

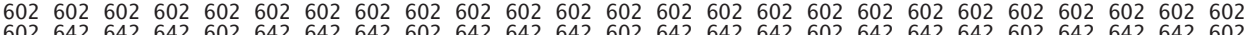
$\begin{array}{lllllllllllllllllllllllll}602 & 642 & 642 & 642 & 602 & 642 & 642 & 642 & 602 & 642 & 642 & 642 & 602 & 642 & 642 & 642 & 602 & 642 & 642 & 642 & 602 & 642 & 642 & 642 & 602\end{array}$ $\begin{array}{lllllllllllllllllllllllll}602 & 642 & 642 & 642 & 602 & 642 & 642 & 642 & 602 & 642 & 642 & 642 & 602 & 642 & 642 & 642 & 602 & 642 & 642 & 642 & 602 & 642 & 642 & 642 & 602 \\ 602 & 642 & 642 & 642 & 602 & 642 & 642 & 642 & 602 & 642 & 642 & 642 & 602 & 642 & 642 & 642 & 602 & 642 & 642 & 642 & 602 & 642 & 642 & 642 & 602\end{array}$

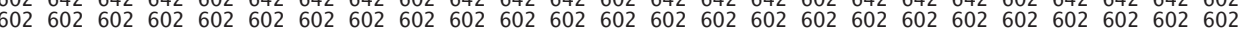

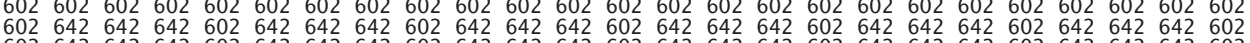
$\begin{array}{lllllllllllllllllllllllll}602 & 642 & 642 & 642 & 602 & 642 & 642 & 642 & 602 & 642 & 642 & 642 & 602 & 642 & 642 & 642 & 602 & 642 & 642 & 642 & 602 & 642 & 642 & 642 & 602 \\ 602 & 442 & 642 & 642 & 602 & 642 & 642 & 642 & 602 & 642 & 642 & 642 & 602 & 642 & 642 & 642 & 602 & 642 & 642 & 642 & 602 & 642 & 642 & 642 & 602\end{array}$ $\begin{array}{lllllllllllllllllllllllll}602 & 642 & 642 & 642 & 602 & 642 & 642 & 642 & 602 & 642 & 642 & 642 & 602 & 642 & 642 & 642 & 602 & 642 & 642 & 642 & 602 & 642 & 642 & 642 & 602 \\ 602 & 602 & 602 & 602 & 602 & 602 & 602 & 602 & 602 & 602 & 602 & 602 & 602 & 602 & 602 & 602 & 602 & 602 & 602 & 602 & 602 & 602 & 602 & 602 & 602\end{array}$ 101101101101101101101101101101101101101101101101101101101101101101101101101 $\begin{array}{lllllllllllllllllllllllll}101 & 441 & 441 & 441 & 101 & 441 & 441 & 441 & 101 & 441 & 441 & 441 & 101 & 441 & 441 & 441 & 101 & 441 & 441 & 441 & 101 & 441 & 441 & 441 & 101\end{array}$ $\begin{array}{llllllllllllllllllllllllllll}101 & 441 & 441 & 441 & 101 & 441 & 441 & 441 & 101 & 441 & 441 & 441 & 101 & 441 & 441 & 441 & 101 & 441 & 441 & 441 & 101 & 441 & 441 & 441 & 101\end{array}$

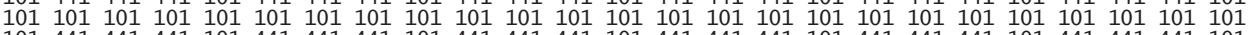

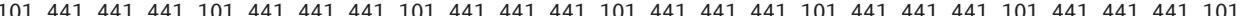

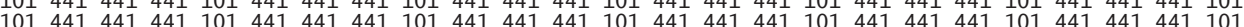

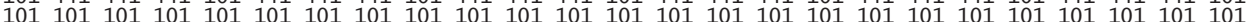
$\begin{array}{lllllllllllllllllllllllll}101 & 101 & 101 & 101 & 101 & 101 & 101 & 101 & 101 & 101 & 101 & 101 & 101 & 101 & 101 & 101 & 101 & 101 & 101 & 101 & 101 & 101 & 101 & 101 & 101 \\ 101 & 441 & 441 & 441 & 101 & 441 & 441 & 441 & 101 & 441 & 441 & 441 & 101 & 441 & 441 & 441 & 101 & 441 & 441 & 441 & 101 & 441 & 441 & 441 & 101\end{array}$ $\begin{array}{lllllllllllllllllllllllllllll}101 & 441 & 441 & 441 & 101 & 441 & 441 & 441 & 101 & 441 & 441 & 441 & 101 & 441 & 441 & 441 & 101 & 441 & 441 & 441 & 101 & 441 & 441 & 441 & 101\end{array}$

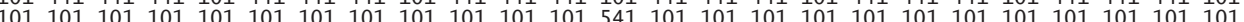

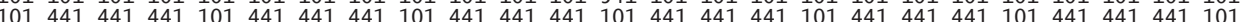
$\begin{array}{llllllllllllllllllllllllllll}101 & 441 & 441 & 441 & 101 & 441 & 441 & 441 & 101 & 441 & 441 & 441 & 101 & 441 & 441 & 441 & 101 & 441 & 441 & 441 & 101 & 441 & 441 & 441 & 101\end{array}$ $\begin{array}{llllllllllllllllllllllllll}101 & 101 & 101 & 101 & 101 & 101 & 101 & 101 & 101 & 101 & 101 & 101 & 101 & 101 & 101 & 101 & 101 & 101 & 101 & 101 & 101 & 101 & 101 & 101 & 101\end{array}$ $101441441441 \quad 101441441441101441441441 \quad 101441441441 \quad 101441441441101441441441 \quad 101$ 101441441441101441441441101441441441101441441441101441441441101441441441101 $\begin{array}{llllllllllllllllllllllllll}101 & 101 & 101 & 101 & 101 & 101 & 101 & 101 & 101 & 101 & 101 & 101 & 101 & 101 & 101 & 101 & 101 & 101 & 101 & 101 & 101 & 101 & 101 & 101 & 101 \\ 101 & 441 & 441 & 441 & 101 & 441 & 441 & 441 & 101 & 441 & 441 & 441 & 101 & 441 & 441 & 441 & 101 & 441 & 441 & 441 & 101 & 441 & 441 & 441 & 101\end{array}$ $\begin{array}{llllllllllllllllllllllllll}101 & 441 & 441 & 441 & 101 & 441 & 441 & 441 & 101 & 441 & 441 & 441 & 101 & 441 & 441 & 441 & 101 & 441 & 441 & 441 & 101 & 441 & 441 & 441 & 101\end{array}$ $\begin{array}{llllllllllllllllllllllllllll}101 & 441 & 441 & 441 & 101 & 441 & 441 & 441 & 101 & 441 & 441 & 441 & 101 & 441 & 441 & 441 & 101 & 441 & 441 & 441 & 101 & 441 & 441 & 441 & 101\end{array}$ $\begin{array}{lllllllllllllllllllllllll}101 & 441 & 441 & 441 & 101 & 441 & 441 & 441 & 101 & 441 & 441 & 441 & 101 & 441 & 441 & 441 & 101 & 441 & 441 & 441 & 101 & 441 & 441 & 441 & 101 \\ 101 & 101 & 101 & 101 & 101 & 101 & 101 & 101 & 101 & 101 & 101 & 101 & 101 & 101 & 101 & 101 & 101 & 101 & 101 & 101 & 101 & 101 & 101 & 101 & 101\end{array}$

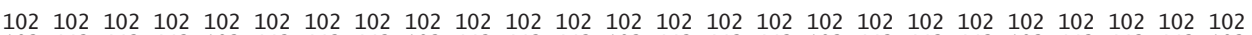

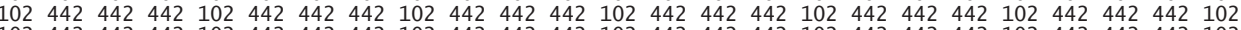
$\begin{array}{lllllllllllllllllllllllll}102 & 442 & 442 & 442 & 102 & 442 & 442 & 442 & 102 & 442 & 442 & 442 & 102 & 442 & 442 & 442 & 102 & 442 & 442 & 442 & 102 & 442 & 442 & 442 & 102 \\ 102 & 442 & 442 & 442 & 102 & 442 & 442 & 442 & 102 & 442 & 442 & 442 & 102 & 442 & 442 & 442 & 102 & 442 & 442 & 442 & 102 & 442 & 442 & 442 & 102\end{array}$ $\begin{array}{lllllllllllllllllllllllllll}102 & 102 & 102 & 102 & 102 & 102 & 102 & 102 & 102 & 102 & 102 & 102 & 102 & 102 & 102 & 102 & 102 & 102 & 102 & 102 & 102 & 102 & 102 & 102 & 102\end{array}$

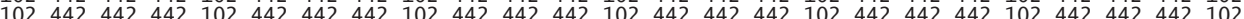
$\begin{array}{lllllllllllllllllllllllll}102 & 442 & 442 & 442 & 102 & 442 & 442 & 442 & 102 & 442 & 442 & 442 & 102 & 442 & 442 & 442 & 102 & 442 & 442 & 442 & 102 & 442 & 442 & 442 & 102\end{array}$

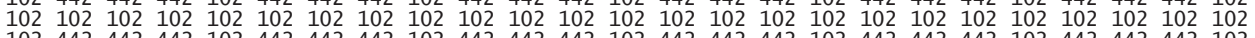

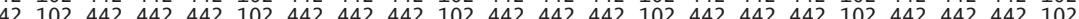
$\begin{array}{llllllllllllllllllllllllllllll}102 & 442 & 442 & 442 & 102 & 442 & 442 & 442 & 102 & 442 & 442 & 442 & 102 & 442 & 442 & 442 & 102 & 442 & 442 & 442 & 102 & 442 & 442 & 442 & 102\end{array}$

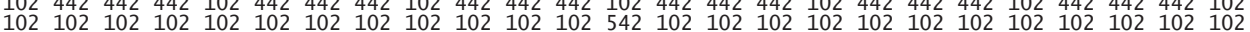
$\begin{array}{lllllllllllllllllllllllllll}102 & 442 & 442 & 442 & 102 & 442 & 442 & 442 & 102 & 442 & 442 & 442 & 102 & 442 & 442 & 442 & 102 & 442 & 442 & 442 & 102 & 442 & 442 & 442 & 102\end{array}$ $\begin{array}{llllllllllllllllllllllllll}102 & 442 & 442 & 442 & 102 & 442 & 442 & 442 & 102 & 442 & 442 & 442 & 102 & 442 & 442 & 442 & 102 & 442 & 442 & 442 & 102 & 442 & 442 & 442 & 102 \\ 102 & 442 & 442 & 442 & 102 & 442 & 442 & 442 & 102 & 442 & 442 & 442 & 102 & 442 & 442 & 442 & 102 & 442 & 442 & 442 & 102 & 442 & 442 & 442 & 102\end{array}$ $\begin{array}{lllllllllllllllllllllllllll}102 & 102 & 102 & 102 & 102 & 102 & 102 & 102 & 102 & 102 & 102 & 102 & 102 & 102 & 102 & 102 & 102 & 102 & 102 & 102 & 102 & 102 & 102 & 102 & 102\end{array}$ $\begin{array}{lllllllllllllllllllllllllll}102 & 442 & 442 & 442 & 102 & 442 & 442 & 442 & 102 & 442 & 442 & 442 & 102 & 442 & 442 & 442 & 102 & 442 & 442 & 442 & 102 & 442 & 442 & 442 & 102\end{array}$ $\begin{array}{lllllllllllllllllllllllllll}102 & 442 & 442 & 442 & 102 & 442 & 442 & 442 & 102 & 442 & 442 & 442 & 102 & 442 & 442 & 442 & 102 & 442 & 442 & 442 & 102 & 442 & 442 & 442 & 102\end{array}$ $\begin{array}{llllllllllllllllllllllllllll}102 & 102 & 102 & 102 & 102 & 102 & 102 & 102 & 102 & 102 & 102 & 102 & 102 & 102 & 102 & 102 & 102 & 102 & 102 & 102 & 102 & 102 & 102 & 102 & 102 \\ 102 & 442 & 442 & 442 & 102 & 442 & 442 & 442 & 102 & 442 & 442 & 442 & 102 & 442 & 442 & 442 & 102 & 442 & 442 & 442 & 102 & 442 & 442 & 442 & 102\end{array}$ $\begin{array}{lllllllllllllllllllllllllll}102 & 442 & 442 & 442 & 102 & 442 & 442 & 442 & 102 & 442 & 442 & 442 & 102 & 442 & 442 & 442 & 102 & 442 & 442 & 442 & 102 & 442 & 442 & 442 & 102 \\ 102 & 442 & 442 & 442 & 102 & 442 & 442 & 442 & 102 & 442 & 442 & 442 & 102 & 442 & 442 & 442 & 102 & 442 & 442 & 442 & 102 & 442 & 442 & 442 & 102\end{array}$ 


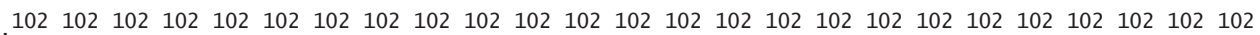
$\begin{array}{lllllllllllllllllllllllll}103 & 103 & 103 & 103 & 103 & 103 & 103 & 103 & 103 & 103 & 103 & 103 & 103 & 103 & 103 & 103 & 103 & 103 & 103 & 103 & 103 & 103 & 103 & 103 & 103\end{array}$ $\begin{array}{llllllllllllllllllllllllll}103 & 443 & 443 & 443 & 103 & 443 & 443 & 443 & 103 & 443 & 443 & 443 & 103 & 443 & 443 & 443 & 103 & 443 & 443 & 443 & 103 & 443 & 443 & 443 & 103 \\ 103 & 443 & 443 & 443 & 103 & 443 & 443 & 443 & 103 & 443 & 443 & 443 & 103 & 443 & 443 & 443 & 103 & 443 & 443 & 443 & 103 & 443 & 443 & 443 & 103\end{array}$ $\begin{array}{lllllllllllllllllllllllll}103 & 443 & 443 & 443 & 103 & 443 & 443 & 443 & 103 & 443 & 443 & 443 & 103 & 443 & 443 & 443 & 103 & 443 & 443 & 443 & 103 & 443 & 443 & 443 & 103 \\ 103 & 443 & 443 & 443 & 103 & 443 & 443 & 443 & 103 & 443 & 443 & 443 & 103 & 443 & 443 & 443 & 103 & 443 & 443 & 443 & 103 & 443 & 443 & 443 & 103\end{array}$ $\begin{array}{lllllllllllllllllllllllll}103 & 103 & 103 & 103 & 103 & 103 & 103 & 103 & 103 & 103 & 103 & 103 & 103 & 103 & 103 & 103 & 103 & 103 & 103 & 103 & 103 & 103 & 103 & 103 & 103\end{array}$ $\begin{array}{lllllllllllllllllllllllll}103 & 443 & 443 & 443 & 103 & 443 & 443 & 443 & 103 & 443 & 443 & 443 & 103 & 443 & 443 & 443 & 103 & 443 & 443 & 443 & 103 & 443 & 443 & 443 & 103 \\ 103 & 443 & 443 & 443 & 103 & 443 & 443 & 443 & 103 & 443 & 443 & 443 & 103 & 443 & 443 & 443 & 103 & 443 & 443 & 443 & 103 & 443 & 443 & 443 & 103\end{array}$ $\begin{array}{lllllllllllllllllllllllll}103 & 443 & 443 & 443 & 103 & 443 & 443 & 443 & 103 & 443 & 443 & 443 & 103 & 443 & 443 & 443 & 103 & 443 & 443 & 443 & 103 & 443 & 443 & 443 & 103\end{array}$

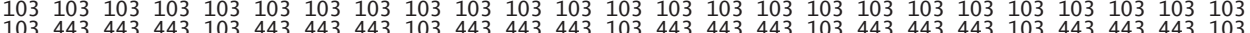

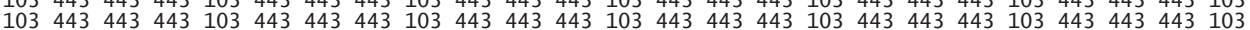

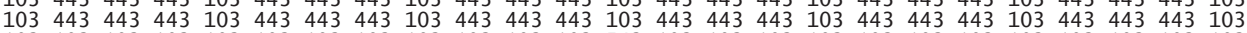

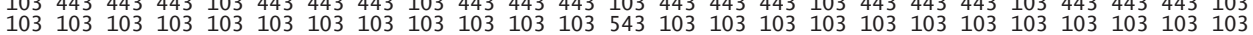

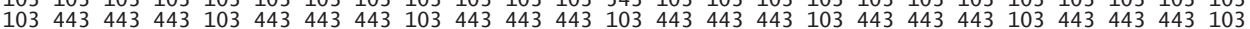

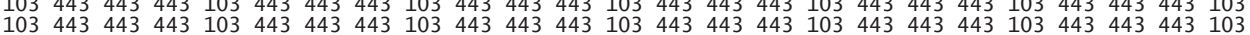
$\begin{array}{lllllllllllllllllllllllll}103 & 443 & 443 & 443 & 103 & 443 & 443 & 443 & 103 & 443 & 443 & 443 & 103 & 443 & 443 & 443 & 103 & 443 & 443 & 443 & 103 & 443 & 443 & 443 & 103 \\ 103 & 443 & 443 & 443 & 103 & 443 & 443 & 443 & 103 & 443 & 443 & 443 & 103 & 443 & 443 & 443 & 103 & 443 & 443 & 443 & 103 & 443 & 443 & 443 & 103\end{array}$ $\begin{array}{lllllllllllllllllllllllllll}103 & 443 & 443 & 443 & 103 & 443 & 443 & 443 & 103 & 443 & 443 & 443 & 103 & 443 & 443 & 443 & 103 & 443 & 443 & 443 & 103 & 443 & 443 & 443 & 103 \\ 103 & 103 & 103 & 103 & 103 & 103 & 103 & 103 & 103 & 103 & 103 & 103 & 103 & 103 & 103 & 103 & 103 & 103 & 103 & 103 & 103 & 103 & 103 & 103\end{array}$ $\begin{array}{lllllllllllllllllllllllll}103 & 443 & 443 & 443 & 103 & 443 & 443 & 443 & 103 & 443 & 443 & 443 & 103 & 443 & 443 & 443 & 103 & 443 & 443 & 443 & 103 & 443 & 443 & 443 & 103 \\ 103 & 443 & 443 & 443 & 103 & 443 & 443 & 443 & 103 & 443 & 443 & 443 & 103 & 443 & 443 & 443 & 103 & 443 & 443 & 443 & 103 & 443 & 443 & 443 & 103\end{array}$

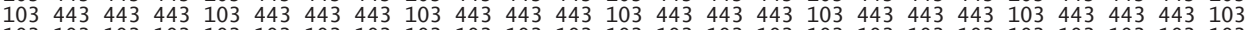
$\begin{array}{lllllllllllllllllllllllllll}103 & 103 & 103 & 103 & 103 & 103 & 103 & 103 & 103 & 103 & 103 & 103 & 103 & 103 & 103 & 103 & 103 & 103 & 103 & 103 & 103 & 103 & 103 & 103 & 103 \\ 103 & 443 & 443 & 443 & 103 & 443 & 443 & 443 & 103 & 443 & 443 & 443 & 103 & 443 & 443 & 443 & 103 & 443 & 443 & 443 & 103 & 443 & 443 & 443 & 103\end{array}$ $\begin{array}{lllllllllllllllllllllllll}103 & 443 & 443 & 443 & 103 & 443 & 443 & 443 & 103 & 443 & 443 & 443 & 103 & 443 & 443 & 443 & 103 & 443 & 443 & 443 & 103 & 443 & 443 & 443 & 103 \\ 103 & 443 & 443 & 443 & 103 & 443 & 443 & 443 & 103 & 443 & 443 & 443 & 103 & 443 & 443 & 443 & 103 & 443 & 443 & 443 & 103 & 443 & 443 & 443 & 103\end{array}$

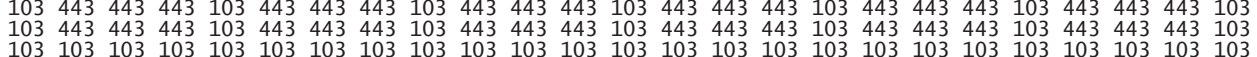

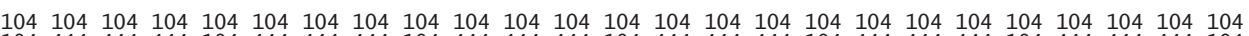

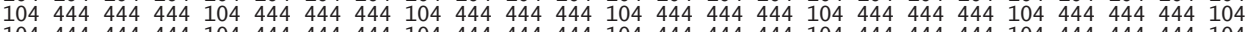

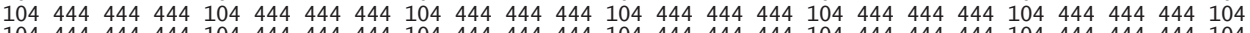

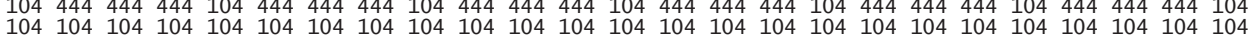
$\begin{array}{lllllllllllllllllllllllll}104 & 444 & 444 & 444 & 104 & 444 & 444 & 444 & 104 & 444 & 444 & 444 & 104 & 444 & 444 & 444 & 104 & 444 & 444 & 444 & 104 & 444 & 444 & 444 & 104\end{array}$

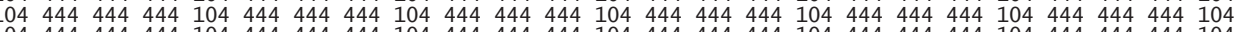

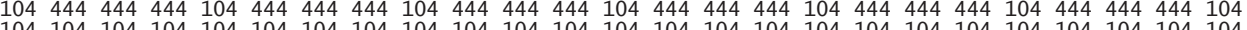

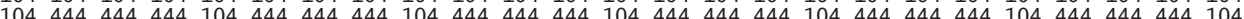

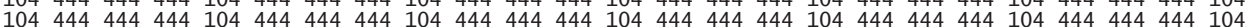

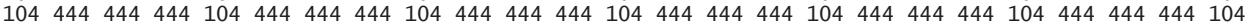

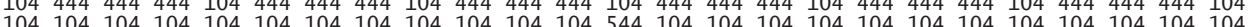

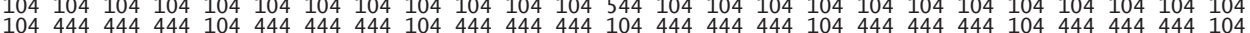

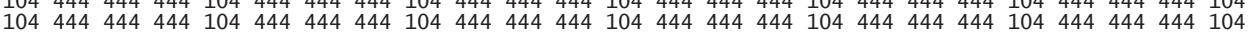

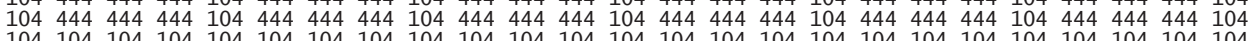

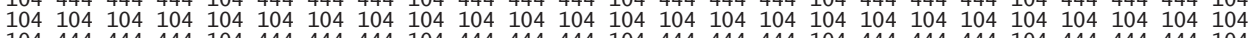

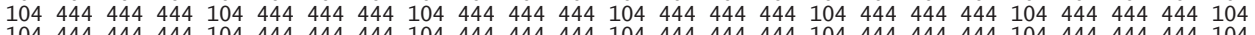

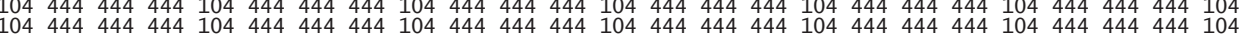

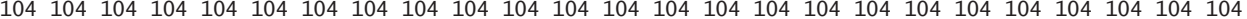

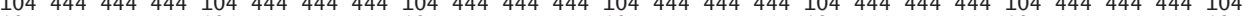
$\begin{array}{lllllllllllllllllllllllll}104 & 444 & 444 & 444 & 104 & 444 & 444 & 444 & 104 & 444 & 444 & 444 & 104 & 444 & 444 & 444 & 104 & 444 & 444 & 444 & 104 & 444 & 444 & 444 & 104 \\ 104 & 444 & 444 & 444 & 104 & 444 & 444 & 444 & 104 & 444 & 444 & 444 & 104 & 444 & 444 & 444 & 104 & 444 & 444 & 444 & 104 & 444 & 444 & 444 & 104\end{array}$ $\begin{array}{lllllllllllllllllllllllll}104 & 444 & 444 & 444 & 104 & 444 & 444 & 444 & 104 & 444 & 444 & 444 & 104 & 444 & 444 & 444 & 104 & 444 & 444 & 444 & 104 & 444 & 444 & 444 & 104 \\ 104 & 104 & 104 & 104 & 104 & 104 & 104 & 104 & 104 & 104 & 104 & 104 & 104 & 104 & 104 & 104 & 104 & 104 & 104 & 104 & 104 & 104 & 104 & 104 & 104\end{array}$ $\begin{array}{lllllllllllllllllllllllll}105 & 105 & 105 & 105 & 105 & 105 & 105 & 105 & 105 & 105 & 105 & 105 & 105 & 105 & 105 & 105 & 105 & 105 & 105 & 105 & 105 & 105 & 105 & 105 & 105\end{array}$ $\begin{array}{lllllllllllllllllllllllll}105 & 445 & 445 & 445 & 105 & 445 & 445 & 445 & 105 & 445 & 445 & 445 & 105 & 445 & 445 & 445 & 105 & 445 & 445 & 445 & 105 & 445 & 445 & 445 & 105 \\ 105 & 445 & 445 & 445 & 105 & 445 & 445 & 445 & 105 & 445 & 445 & 445 & 105 & 445 & 445 & 445 & 105 & 445 & 445 & 445 & 105 & 445 & 445 & 445 & 105\end{array}$

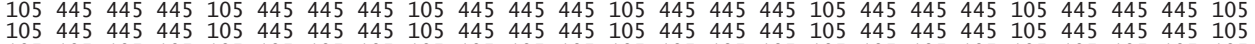

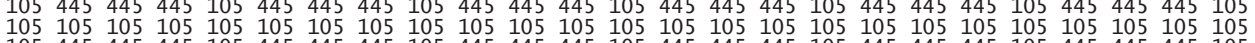
$\begin{array}{llllllllllllllllllllllllll}105 & 445 & 445 & 445 & 105 & 445 & 445 & 445 & 105 & 445 & 445 & 445 & 105 & 445 & 445 & 445 & 105 & 445 & 445 & 445 & 105 & 445 & 445 & 445 & 105\end{array}$

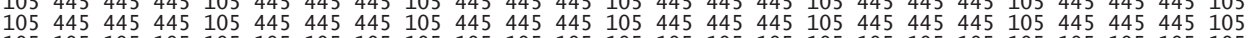
$\begin{array}{llllll} & \end{array}$

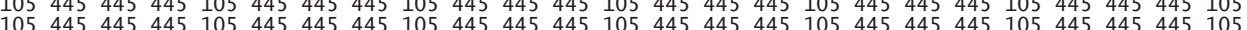

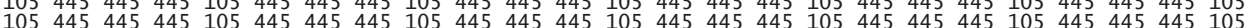

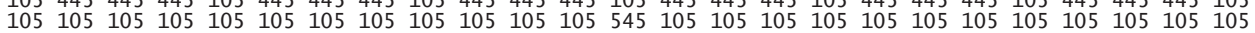

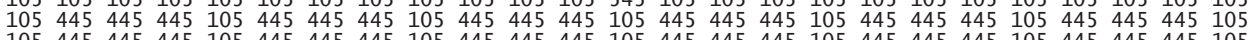

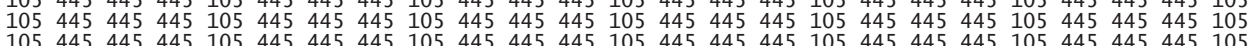
$\begin{array}{lllllllllllllllllllllllll}105 & 445 & 445 & 445 & 105 & 445 & 445 & 445 & 105 & 445 & 445 & 445 & 105 & 445 & 445 & 445 & 105 & 445 & 445 & 445 & 105 & 445 & 445 & 445 & 105 \\ 105 & 105 & 105 & 105 & 105 & 105 & 105 & 105 & 105 & 105 & 105 & 105 & 105 & 105 & 105 & 105 & 105 & 105 & 105 & 105 & 105 & 105 & 105 & 105 & 105\end{array}$ $\begin{array}{llllllllllllll}105 & 105 & 105 & 105 & 105 & 105 & 105 & 105 & 105 & 105 & 105 & 105 & 10 & \\ 105 & 45 & 45 & 45 & 105 & 445 & 445 & 45 & 105 & 445 & 445 & 445 & 10 & 0\end{array}$

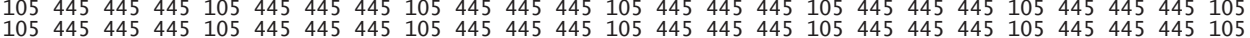
$\begin{array}{lllllllllllllllllllllllll}105 & 445 & 445 & 445 & 105 & 445 & 445 & 445 & 105 & 445 & 445 & 445 & 105 & 445 & 445 & 445 & 105 & 445 & 445 & 445 & 105 & 445 & 445 & 445 & 105 \\ 105 & 105 & 105 & 105 & 105 & 105 & 105 & 105 & 105 & 105 & 105 & 105 & 105 & 105 & 105 & 105 & 105 & 105 & 105 & 105 & 105 & 105 & 105 & 105 & 105\end{array}$ $\begin{array}{llllllllllll} & \end{array}$ $\begin{array}{llllllllllllllllllllllllll}105 & 445 & 445 & 445 & 105 & 445 & 445 & 445 & 105 & 445 & 445 & 445 & 105 & 445 & 445 & 445 & 105 & 445 & 445 & 445 & 105 & 445 & 445 & 445 & 105 \\ 105 & 445 & 445 & 445 & 105 & 445 & 445 & 445 & 105 & 445 & 445 & 445 & 105 & 445 & 445 & 445 & 105 & 445 & 445 & 445 & 105 & 445 & 445 & 445 & 105\end{array}$ $\begin{array}{llllllllllllllllllllllllllll}105 & 445 & 445 & 445 & 105 & 445 & 445 & 445 & 105 & 445 & 445 & 445 & 105 & 445 & 445 & 445 & 105 & 445 & 445 & 445 & 105 & 445 & 445 & 445 & 105 \\ 105 & 105 & 105 & 105 & 105 & 105 & 105 & 105 & 105 & 105 & 105 & 105 & 105 & 105 & 105 & 105 & 105 & 105 & 105 & 105 & 105 & 105 & 105 & 105 & 105\end{array}$

$106106106106106106106106106106106106106106106106106106106106 \quad 106 \quad 106 \quad 106 \quad 106 \quad 106$

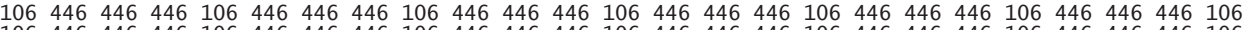

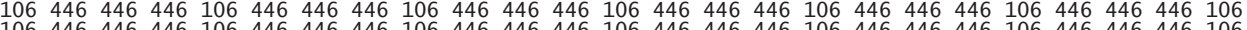

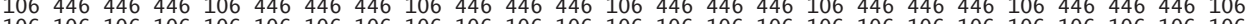
$\begin{array}{lllllllllllllllllllllllll}106 & 106 & 106 & 106 & 106 & 106 & 106 & 106 & 106 & 106 & 106 & 106 & 106 & 106 & 106 & 106 & 106 & 106 & 106 & 106 & 106 & 106 & 106 & 106 & 106\end{array}$

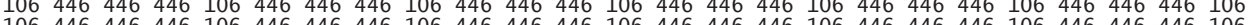
$106 \quad 446 \quad 446 \quad 446 \quad 106 \quad 446 \quad 446 \quad 446106 \quad 446 \quad 446 \quad 446 \quad 106 \quad 446 \quad 446446106446446446106446 \quad 446446106$

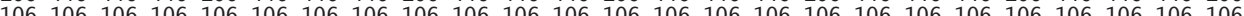
$106 \quad 446 \quad 446 \quad 446 \quad 106 \quad 446 \quad 446 \quad 446 \quad 106 \quad 446 \quad 446 \quad 446 \quad 106 \quad 446 \quad 446 \quad 446 \quad 106446 \quad 446446106446 \quad 446446106$ $106 \quad 446 \quad 446 \quad 446 \quad 106 \quad 446 \quad 446 \quad 446 \quad 106 \quad 446 \quad 446 \quad 446 \quad 106 \quad 446 \quad 446 \quad 446 \quad 106 \quad 446 \quad 446446106 \quad 446 \quad 446 \quad 446 \quad 106$

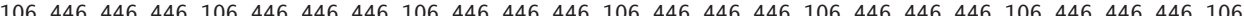

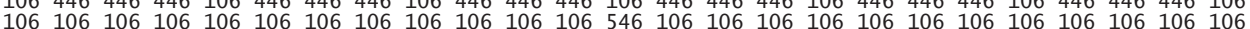

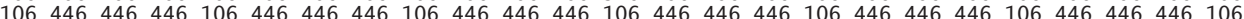

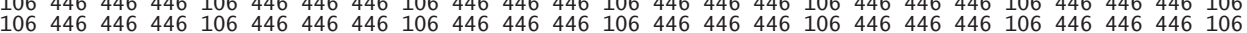
$\begin{array}{llllllllllllllllllllllllll}106 & 446 & 446 & 446 & 106 & 446 & 446 & 446 & 106 & 446 & 446 & 446 & 106 & 446 & 446 & 446 & 106 & 446 & 446 & 446 & 106 & 446 & 446 & 446 & 106\end{array}$ $\begin{array}{llllllllllllllllllllllllll}106 & 106 & 106 & 106 & 106 & 106 & 106 & 106 & 106 & 106 & 106 & 106 & 106 & 106 & 106 & 106 & 106 & 106 & 106 & 106 & 106 & 106 & 106 & 106 & 106\end{array}$

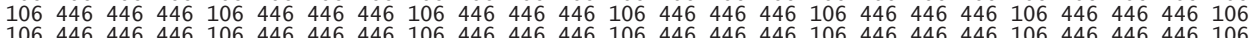
$106446446 \quad 446106446446446106446446446106446446446106446446446106446446446 \quad 106$

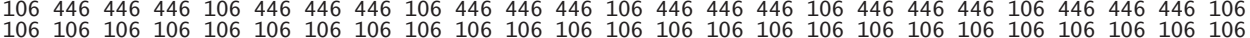

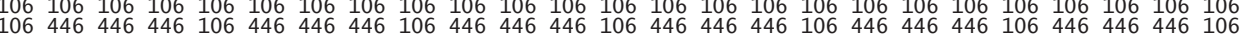

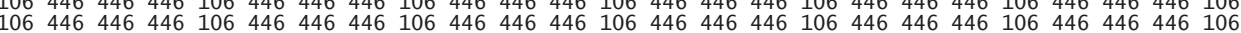
$\begin{array}{lllllllllllllllllllllllll}106 & 446 & 446 & 446 & 106 & 446 & 446 & 446 & 106 & 446 & 446 & 446 & 106 & 446 & 446 & 446 & 106 & 446 & 446 & 446 & 106 & 446 & 446 & 446 & 106 \\ 106 & 106 & 106 & 106 & 106 & 106 & 106 & 106 & 106 & 106 & 106 & 106 & 106 & 106 & 106 & 106 & 106 & 106 & 106 & 106 & 106 & 106 & 106 & 106 & 106\end{array}$

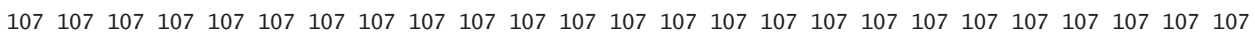


$\begin{array}{lllllllllllllllllllllllll}107 & 447 & 447 & 447 & 107 & 447 & 447 & 447 & 107 & 447 & 447 & 447 & 107 & 447 & 447 & 447 & 107 & 447 & 447 & 447 & 107 & 447 & 447 & 447 & 107\end{array}$ $\begin{array}{llllllllllllllllllllllllll}107 & 447 & 447 & 447 & 107 & 447 & 447 & 447 & 107 & 447 & 447 & 447 & 107 & 447 & 447 & 447 & 107 & 447 & 447 & 447 & 107 & 447 & 447 & 447 & 107 \\ 107 & 447 & 447 & 447 & 107 & 447 & 447 & 447 & 107 & 447 & 447 & 447 & 107 & 447 & 447 & 447 & 107 & 447 & 447 & 447 & 107 & 447 & 447 & 447 & 107\end{array}$

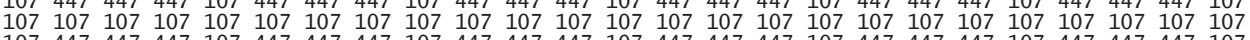
$\begin{array}{llllllllllllllllllllllllll}107 & 447 & 447 & 447 & 107 & 447 & 447 & 447 & 107 & 447 & 447 & 447 & 107 & 447 & 447 & 447 & 107 & 447 & 447 & 447 & 107 & 447 & 447 & 447 & 107\end{array}$ $\begin{array}{llllllllllllllllllllllllll}107 & 447 & 447 & 447 & 107 & 447 & 447 & 447 & 107 & 447 & 447 & 447 & 107 & 447 & 447 & 447 & 107 & 447 & 447 & 447 & 107 & 447 & 447 & 447 & 107\end{array}$

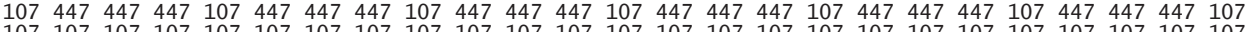

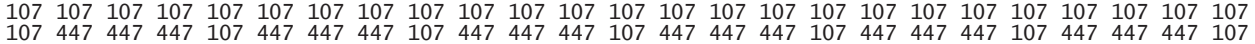

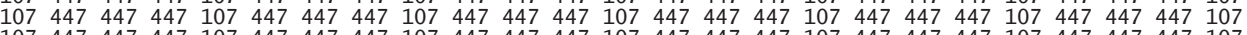

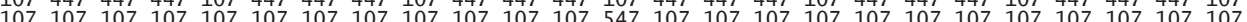

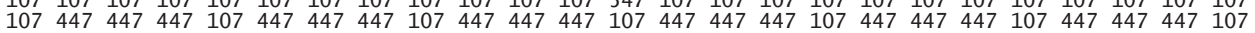
$\begin{array}{llllllllllllllllllllllllll}107 & 447 & 447 & 447 & 107 & 447 & 447 & 447 & 107 & 447 & 447 & 447 & 107 & 447 & 447 & 447 & 107 & 447 & 447 & 447 & 107 & 447 & 447 & 447 & 107 \\ 107 & 447 & 447 & 447 & 107 & 447 & 447 & 447 & 107 & 447 & 447 & 447 & 107 & 447 & 447 & 447 & 107 & 447 & 447 & 447 & 107 & 447 & 447 & 447 & 107 \\ 107 & 447 & 447 & 447 & 107 & 447 & 447 & 447 & 107 & 447 & 447 & 447 & 107 & 447 & 447 & 447 & 107 & 447 & 447 & 447 & 107 & 447 & 447 & 447 & 107\end{array}$

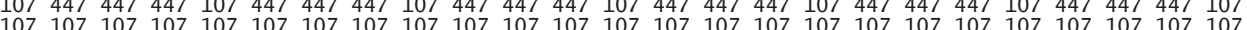

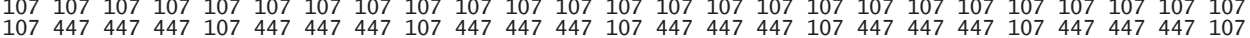

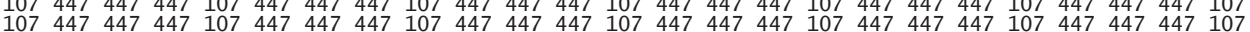

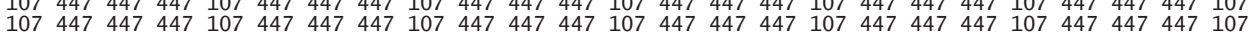

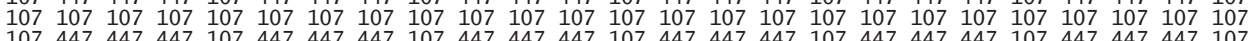

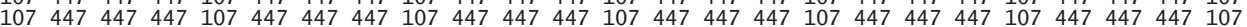
$\begin{array}{llllllllllllllllllllllllll}107 & 447 & 447 & 447 & 107 & 447 & 447 & 447 & 107 & 447 & 447 & 447 & 107 & 447 & 447 & 447 & 107 & 447 & 447 & 447 & 107 & 447 & 447 & 447 & 107 \\ 107 & 107 & 107 & 107 & 107 & 107 & 107 & 107 & 107 & 107 & 107 & 107 & 107 & 107 & 107 & 107 & 107 & 107 & 107 & 107 & 107 & 107 & 107 & 107 & 107\end{array}$

$\begin{array}{lllllllllllllllllllllllll}108 & 108 & 108 & 108 & 108 & 108 & 108 & 108 & 108 & 108 & 108 & 108 & 108 & 108 & 108 & 108 & 108 & 108 & 108 & 108 & 108 & 108 & 108 & 108 & 108\end{array}$ $\begin{array}{lllllllllllllllllllllllll}108 & 448 & 448 & 448 & 108 & 448 & 448 & 448 & 108 & 448 & 448 & 448 & 108 & 448 & 448 & 448 & 108 & 448 & 448 & 448 & 108 & 448 & 448 & 448 & 108\end{array}$ $\begin{array}{lllllllllllllllllllllllll}108 & 448 & 448 & 448 & 108 & 448 & 448 & 448 & 108 & 448 & 448 & 448 & 108 & 448 & 448 & 448 & 108 & 448 & 448 & 448 & 108 & 448 & 448 & 448 & 108 \\ 108 & 448 & 448 & 448 & 108 & 448 & 448 & 448 & 108 & 448 & 448 & 448 & 108 & 448 & 448 & 448 & 108 & 448 & 448 & 448 & 108 & 448 & 448 & 448 & 108\end{array}$

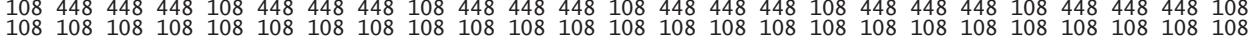

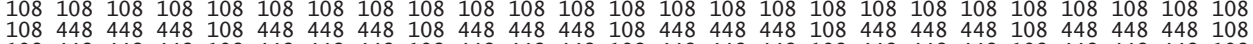

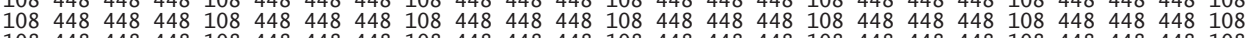

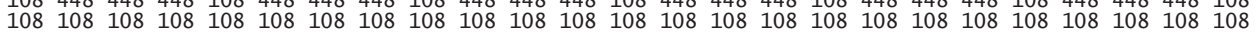

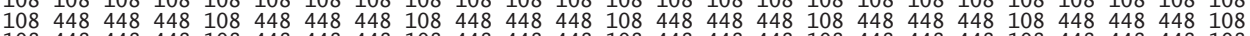

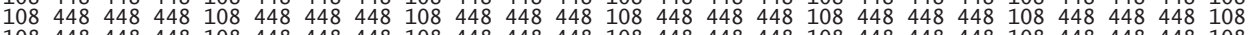

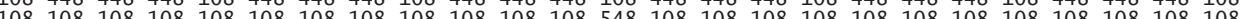

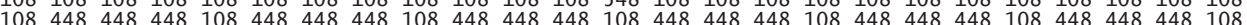

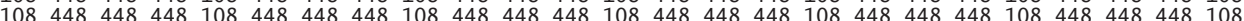

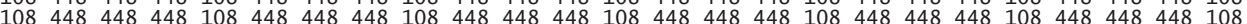

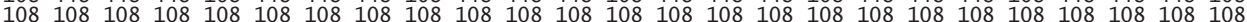
$\begin{array}{llllllllllllllllllllllllll}108 & 448 & 448 & 448 & 108 & 448 & 448 & 448 & 108 & 448 & 448 & 448 & 108 & 448 & 448 & 448 & 108 & 448 & 448 & 448 & 108 & 448 & 448 & 448 & 108\end{array}$

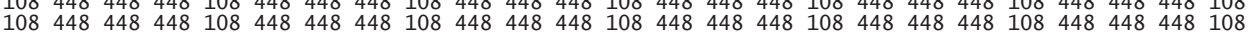

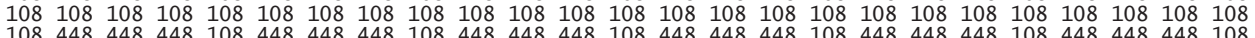
$\begin{array}{llllllllllllllllllllllllll}108 & 448 & 448 & 448 & 108 & 448 & 448 & 448 & 108 & 448 & 448 & 448 & 108 & 448 & 448 & 448 & 108 & 448 & 448 & 448 & 108 & 448 & 448 & 448 & 108\end{array}$

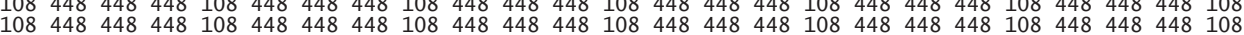

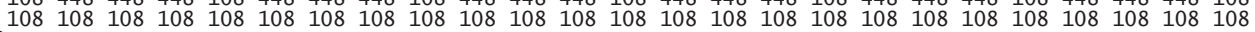
$\begin{array}{lllllllllllllllllllllllll}109 & 109 & 109 & 109 & 109 & 109 & 109 & 109 & 109 & 109 & 109 & 109 & 109 & 109 & 109 & 109 & 109 & 109 & 109 & 109 & 109 & 109 & 109 & 109 & 109\end{array}$

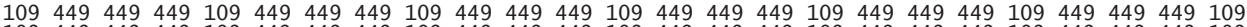

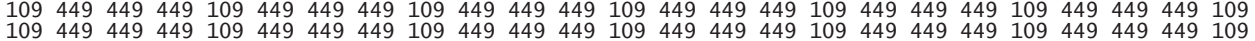

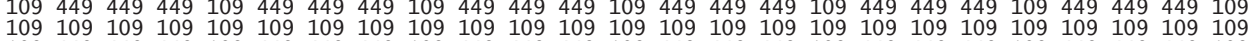
449 44910944944409

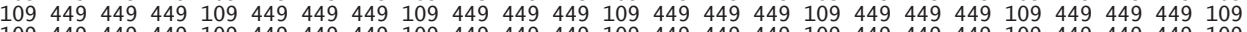
109 1094409

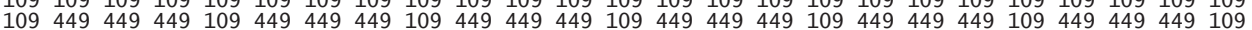

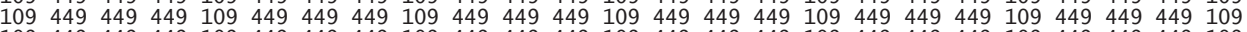
$\begin{array}{lllllllllll} & \end{array}$

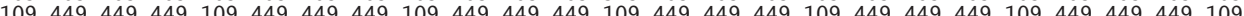

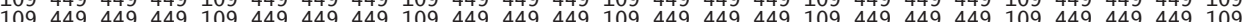

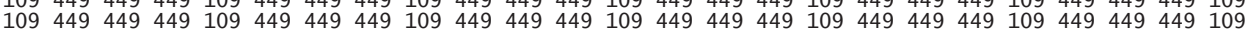
109 10909

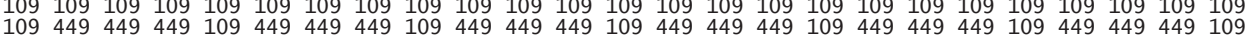

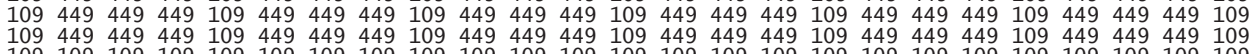

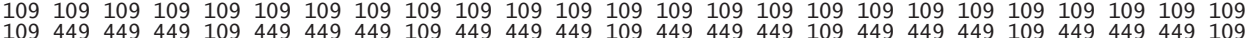

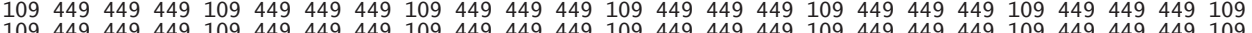

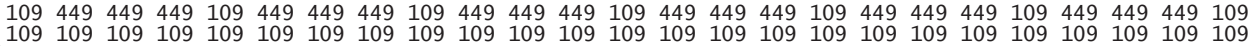

$\begin{array}{lllllllllllllllllllllllll}110 & 110 & 110 & 110 & 110 & 110 & 110 & 110 & 110 & 110 & 110 & 110 & 110 & 110 & 110 & 110 & 110 & 110 & 110 & 110 & 110 & 110 & 110 & 110 & 110\end{array}$

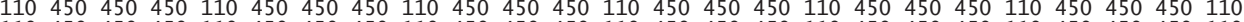

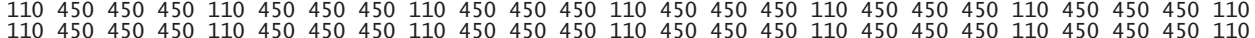

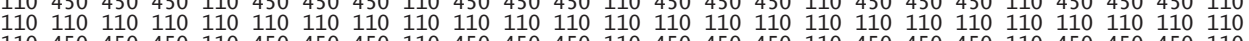

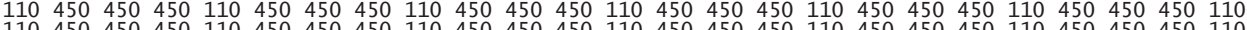

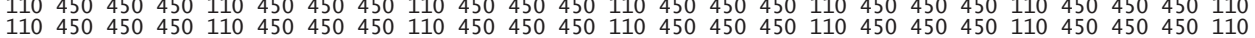

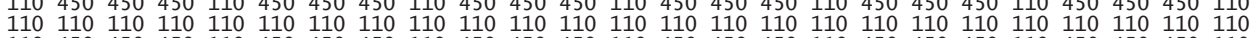

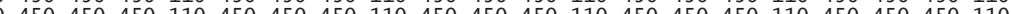

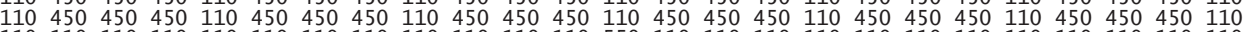

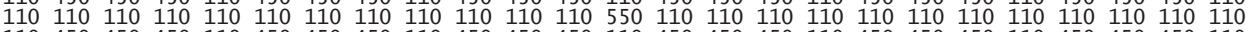

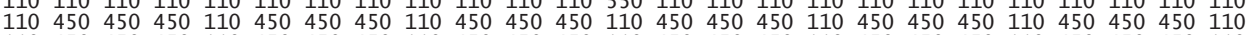

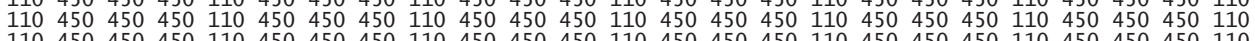

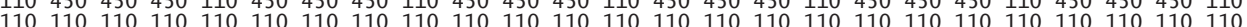

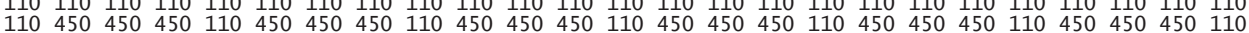

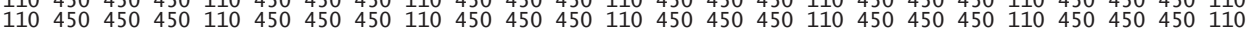

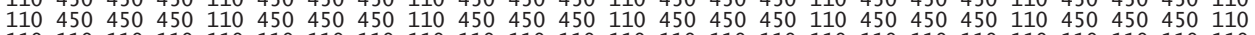
$\begin{array}{lllllllllllllllllllllllll}110 & 110 & 110 & 110 & 110 & 110 & 110 & 110 & 110 & 110 & 110 & 110 & 110 & 110 & 110 & 110 & 110 & 110 & 110 & 110 & 110 & 110 & 110 & 110 & 110\end{array}$ $\begin{array}{lllllllllllllllllllllllll}110 & 450 & 450 & 450 & 110 & 450 & 450 & 450 & 110 & 450 & 450 & 450 & 110 & 450 & 450 & 450 & 110 & 450 & 450 & 450 & 110 & 450 & 450 & 450 & 110\end{array}$ $\begin{array}{lllllllllllllllllllllllll}110 & 450 & 450 & 450 & 110 & 450 & 450 & 450 & 110 & 450 & 450 & 450 & 110 & 450 & 450 & 450 & 110 & 450 & 450 & 450 & 110 & 450 & 450 & 450 & 110 \\ 110 & 110 & 110 & 110 & 110 & 110 & 110 & 110 & 110 & 110 & 110 & 110 & 110 & 110 & 110 & 110 & 110 & 110 & 110 & 110 & 110 & 110 & 110 & 110 & 110\end{array}$ $\begin{array}{lllllllllllllllllllllllll}603 & 603 & 603 & 603 & 603 & 603 & 603 & 603 & 603 & 603 & 603 & 603 & 603 & 603 & 603 & 603 & 603 & 603 & 603 & 603 & 603 & 603 & 603 & 603 & 603\end{array}$

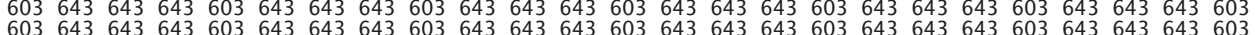
$\begin{array}{lllllllllllllllllllllllllll}603 & 643 & 643 & 643 & 603 & 643 & 643 & 643 & 603 & 643 & 643 & 643 & 603 & 643 & 643 & 643 & 603 & 643 & 643 & 643 & 603 & 643 & 643 & 643 & 603 \\ 603 & 643 & 643 & 643 & 603 & 643 & 643 & 643 & 603 & 643 & 643 & 643 & 603 & 643 & 643 & 643 & 603 & 643 & 643 & 643 & 603 & 643 & 643 & 643 & 603\end{array}$ 


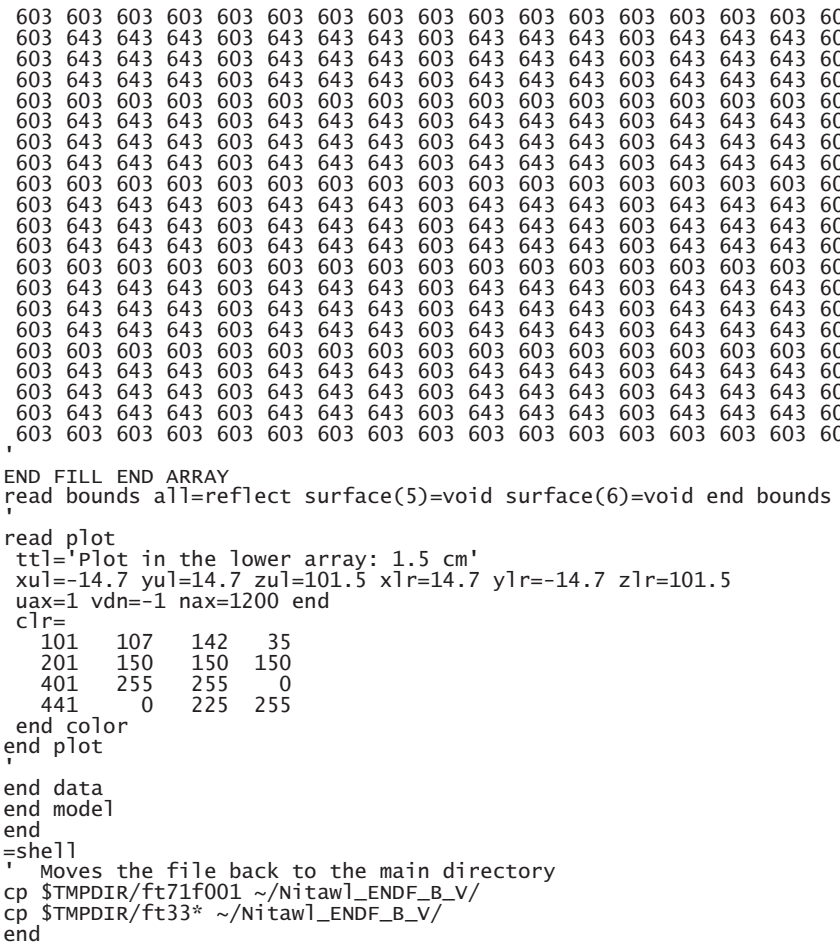




\section{APPENDIX B}

\section{OPUS input and nuclide concentrations post-processing}

The OPUS input for the extraction of the nuclei associated with the TRITON/Keno-V input shown in Appendix A is shown in this appendix.

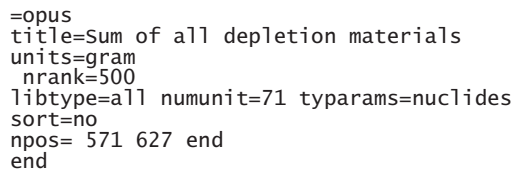

The nuclei densities are stored in the $\mathrm{ft} 71 \mathrm{f001}$ file, in binary format.

OPUS can extract the nuclei concentrations at given "time dumps". In this model there are 10 axial depletion zones; each depletion zone produces 57 time dumps based on the depletion story required in this case. The time dumps for all the zones combined are from 571 to 627 . TRITON produces a summary table with a list of all time dumps: it can be obtained by searching "time dumps found on this set of libraries" and using the values in the 1st column, titled "Position".

The file $\mathrm{ft} 71 \mathrm{f} 001$ has to be in the temporary work directory of SCALE to be easily found. It is recommended, however, to save a copy of this file in the input/output directory for future reference.

If the volume of fuel is not entered, it is assumed to be (by default) that of $1 \mathrm{MT}$ of $\mathrm{HM}$ of $\mathrm{UO}_{2}$.

The downloaded inventory for all the zones combined, as calculated and extracted by OPUS, is correctly volume-weighted over the entire system. This was verified at BOL, when the weight enrichment for the fuel is known. The expected average enrichment of the assembly at BOL can be easily calculated to be $4.93 \%$, matching exactly the value extracted by OPUS for the BOL masses at "time dump" 571.

A FORTRAN utility was created to collect the nuclei masses printed in the output and sort them in the same order as in the transmutation library maintained by the campaign. 


\section{APPENDIX C}

\section{XSECLIST input and cross sections post-processing}

The one-group cross section can be extracted by the XSECLIST SCALE utility from the data saved in the binary files $f t 33 f 001$. In the model used for this work there are 10 depletion zones, named 101 to 110 , so $11 \mathrm{ft} 33 \mathrm{f} 001$ files will be generated: ft33f001.mix0101 to ft33f001.mix 0110, plus one called $f t 33 f 001 . c m b i n e d$ which contains the flux-weighted cross sections for the entire system.

The manual of the XSECLIST utility is a section at the end of the ORIGEN-ARP manual, so it may be difficult to find if the location is not known "a priori" (Section D1.B.11).

The input of XSECLIST is the following:

=xsec 1 ist

SCWR_13.arp1ib

15

3

The name of the file "SCWR_13.arplib" is one of the ft33f001 files (in this case ft33f001.cmbined) renominated with the "arplib" extension and located in the $C: /$ scale5.1/data/arplibs directory for scale5.1, among the other pre-generated arplib data files.

15 is the number of burnup steps, and 1-15 list the burnup steps for which the cross sections are desired. 
The list of nuclei contains the complete 1022 available nuclei list as sorted in the cross section libraries maintained by the campaign. 


\section{APPENDIX D}

\section{SCALE XSLIST READER for the conversion of OPUS and XSECLIST outputs to the standard format of the transmutation library}

A FORTRAN utility was created to collect the cross sections printed in the output and sort them in the same order as in the cross section library maintained by the campaign. The most recent version of the utility (SCALE_XSLIST_READER.exe) was created on $21^{\text {st }}$ June 2012.

The input of the utility is in a file called list.inp, the (partial) input of which is listed below:

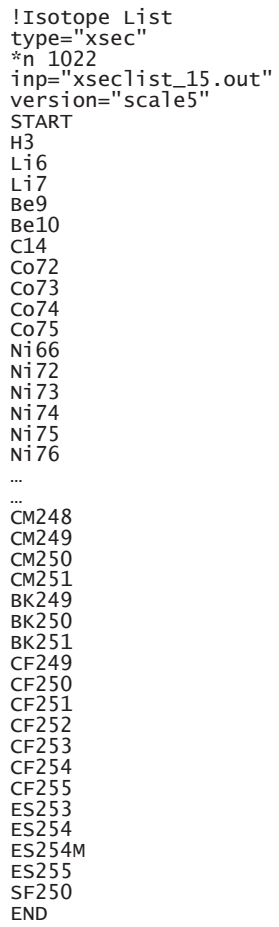

- The type keyword can assume the values xsec or opus for, respectively, sorting the 1 group cross sections or the nuclei densities;

- The $\mathbf{1 0 2 2}$ value is number of nuclei for which data are extracted, and are listed after the $\boldsymbol{S T A R T}$ keyword in the correct order of desired sorting;

- The input keyword contains the opus of xseclist output file, input to this converter;

- The version keyword can assume the values scale5 or scale6 for, respectively, SCALE5.1 output and SCALE 6.0 or SCALE6.1 outputs.

The output of the sorting will be called opus-converted.out or xsec-converted.out.

The nuclei sums in the opus-converted.out output are not calculated, but copied from the opus output. Theactual total mass of the nuclei can be different from the value reported in the opus-converted.out, for example, because the ${ }^{16} \mathrm{O}$ mass in $\mathrm{UO}_{2}$ fuel is not included in the transmutation library. The masses are not normalized, so they will need to be divided by the total mass calculated externally to the subroutine. This is an example where SCALE5.0, SCALE5.1 and SCALE6.0 differ from SCALE6.1: in SCALE6.1 
the extracted cross sections are already calculated over the entire spectrum, so they do not need to be renormalized.

Regarding the XS post processing (raws: nuclei, columns: burnup steps), the values are not in barns. They will need to be multipled by the ratio of thermal to total fluxes to obtain barns. The thermal and total fluxes can be obtained by the Transport tables in the standard TRITON output: the one at Burnup $=0$ GWD/MTiHM is reported, as an example, below.

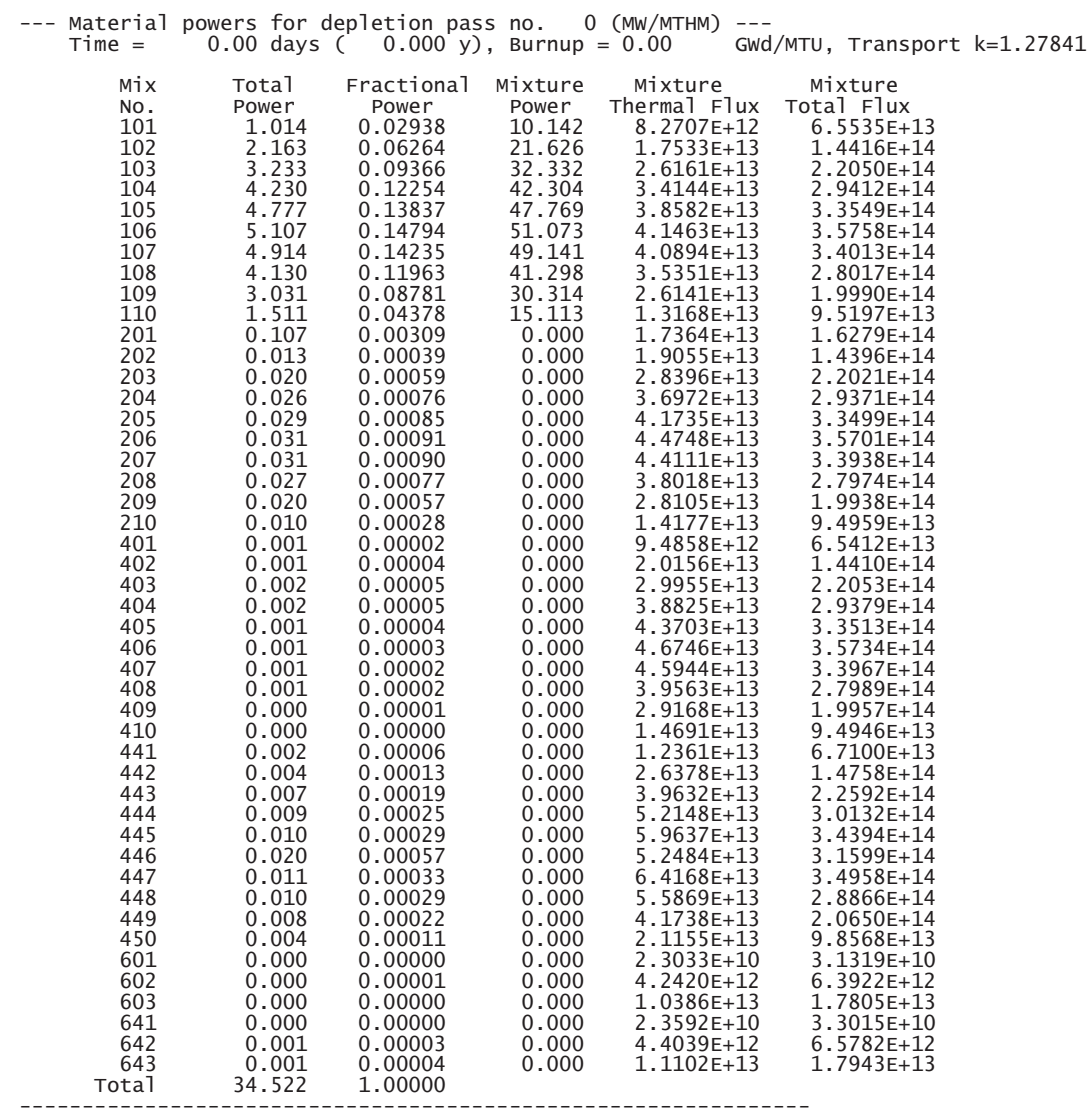

In the case of this study, where there are multiple mixtures, it was decided (somewhat arbitrarily) to use the ratio of the sums of the thermal and total fluxes of all the zones as a normalization factor. 